\title{
Influence of Aromatic Cations on the Structural Arrangement of $\mathrm{Hg}$ (II) Halides
}

\author{
Francisco Sánchez-Férez, Xavier Solans-Monfort, Teresa Calvet, Mercè Font-Bardia, and Josefina Pons*
}

Cite This: ACS Omega 2020, 5, 29357-29372

Read Online

ABSTRACT: Understanding the structure and arrangement of hybrid metal halides and their contribution to the optoelectronic properties is, thus far, a challenging topic. In particular, new materials composed of $\mathrm{d}^{10}$ metal halides and pyridinium cations are still largely unexplored. Therefore, we report the synthesis and characterization of six $\mathrm{Hg}(\mathrm{II})$ salts built up from $\left(\mathrm{Hg}_{2} \mathrm{Cl}_{6}\right)^{2-}$ or $\left(\mathrm{HgX}_{4}\right)^{2-}$ anions $(\mathrm{X}=\mathrm{Cl}, \mathrm{Br}, \mathrm{I})$ and $2,2^{\prime}$-bipyridium $\left(2,2^{\prime}\right.$ Hbipy $)^{+}, 2,2^{\prime}$-bipyridine-1,1'-diium $\left(2,2^{\prime}-\mathrm{H}_{2} \text { bipy }\right)^{2+}$, or 1,10 phenantrolinium $(1,10-\mathrm{Hphen})^{+}$cations, using the same experimental conditions. All of them have been characterized by PXRD, EA, FTIR-ATR, and ${ }^{1} \mathrm{H}$ NMR spectroscopies; single-crystal X-ray diffraction; and TG/DTA determinations. The study of their

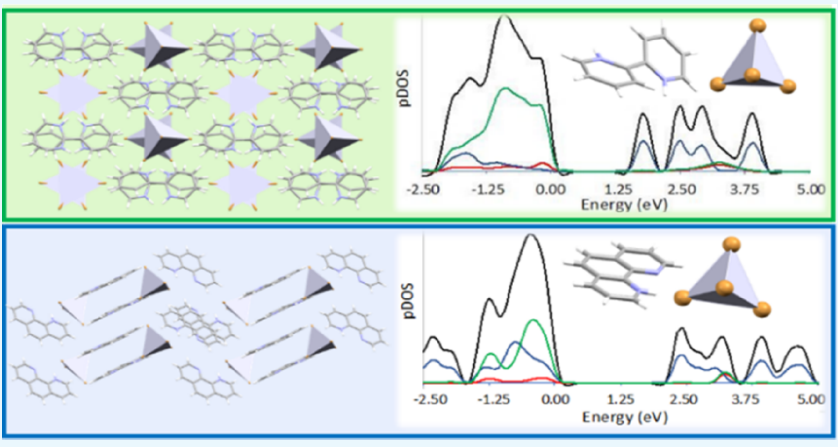
packing via Hirshfeld surface analysis and 3D deformation density mapping revealed the contributions of the intermolecular interactions to the structural arrangement, notably, the effect of the cation planarity on them. Successively, periodic DFT calculations showed that (i) the valence and conducting bands are mainly composed of the $\mathrm{p}$ orbitals of the halide and the organic cation, respectively, and (ii) the corresponding band gap depends mainly on the halide.

\section{INTRODUCTION}

The study of hybrid organic-inorganic materials composed of metal halide anions and ammonium-based organic cations has suffered a rekindled interest flagged by their application in optoelectronic devices. Their solvent processability and easy fabrication in combination with their structural tunability distinguished them as promising materials. ${ }^{1,2}$

As their structural arrangement directly affects the electronic properties, thoroughgoing studies on the effects of anion and cation into the final packing and their influence on the band gap are required. Indeed, the structural features of the cation (size, planarity, and aromaticity) conjointly with those of the anion (size, geometrical metal preferences, and halide dimensions $)^{3}$ are known to drive the assembly of the inorganic units through their intermolecular interactions (electrostatic, $\pi \cdots \pi$ stacking, anion $\cdots \pi$, and $\sigma$-hole effects). ${ }^{4-9}$

Notwithstanding the extensive research done with primary amines and in a lesser extent with aromatic rings, ${ }^{10}$ the studies incorporating pyridinium cations are scarce.,11 Howbeit, aromatic cations were proven to be remarkable candidates for preparing light-emitting compounds. ${ }^{12}$ While alkyl ammonium cations tend to form layered arrays, ${ }^{13,14}$ even more pronounced with large cations, ${ }^{15}$ their replacement with bipyridinium rings with a delocalized $\pi$-electron character may, at the same time, modify the packing and the electronic properties.

Within this frame, there has been extensive research on $\mathrm{Sn}(\mathrm{II}), \mathrm{Pb}(\mathrm{II})$, and $\mathrm{Ge}(\mathrm{II})$ halides but less on $\mathrm{Zn}(\mathrm{II}), \mathrm{Cd}(\mathrm{II})$, and $\mathrm{Hg}(\mathrm{II})^{16-21}$ being prospective homovalent candidates. In previous papers, $\mathrm{Hg}$ (II) halides containing alkylammonium cations inter alia, $\left(\mathrm{C}_{3} \mathrm{H}_{12} \mathrm{~N}_{2}\right)\left(\mathrm{HgCl}_{4}\right)^{22}$ and $\left(\mathrm{C}_{4} \mathrm{H}_{14} \mathrm{~N}_{2}\right)$ $\left(\mathrm{HgCl}_{4}\right),{ }^{23}$ presented corner-sharing $\mathrm{HgCl}_{6}$ octahedra with $\left(\mathrm{HgCl}_{4}\right)^{2-}$ units forming layers separated by the bifunctional ammonium cations. The larger aliphatic chain of $\left(\mathrm{C}_{4} \mathrm{H}_{14} \mathrm{~N}_{2}\right)^{2+}$ favored van der Waals interactions, better stacking the cations and favoring the shorter separation of the inorganic layers. Their substitution by benzidinium cations in $\left(\mathrm{NH}_{3}\left(\mathrm{C}_{6} \mathrm{H}_{4}\right)_{2} \mathrm{NH}_{3}\right)\left(\mathrm{HgCl}_{4}\right)^{24}$ modified the inorganic connectivity, constructing tetrahedral $\mathrm{HgCl}_{4}$ units but preserving the layered structure. In this case study, the aromatic benzidinium cations did not form $\pi \cdots \pi$ stacking interactions, which favored the separation of the inorganic units.

In addition, their spherical $\mathrm{d}^{10}$ closed-shell electronic configuration stands out for promoting the electronic transitions to occur through ligand-centered (LC) and ligand-to-ligand charge transfer (LLCT) and hence excels at presenting photophysical properties. ${ }^{25}$ In this sense, to the best of our knowledge, there is no previously reported study on the

Received: August 28, 2020

Accepted: October 16, 2020

Published: November 6, 2020 
optoelectronic properties of $\mathrm{Hg}$ (II) halides incorporating pyridinium cations.

Our group has previously explored the structural behavior of $\mathrm{d}^{10}$ metal ions in the presence of either carboxylic aromatic ligands or combined with $\mathrm{N}$-donor aromatic ligands, relating it with their photophysical properties. ${ }^{26-28}$ In this contribution, we focused on $\mathrm{Hg}$ (II) halides in the presence of $\mathrm{N}$-donor aromatic conjugated cations being 2,2'-bipyridium $\left(2,2^{\prime}\right.$ Hbipy $)^{+}, 2,2^{\prime}$-bipyridine-1,1'-diium $\left(2,2^{\prime}-\mathrm{H}_{2} \text { bipy }\right)^{2+}$, and 1,10 phenantrolinium $(1,10-\mathrm{Hphen})^{+}$, bearing on their different planarity and bulkiness. Herein, the synthesis of six hybrid $\mathrm{Hg}$ (II) halides, (2,2'-Hbipy $)_{2}\left(\mathrm{Hg}_{2} \mathrm{Cl}_{6}\right)$ (1), (2,2'- $\mathrm{H}_{2}$ bipy)$\left(\mathrm{HgX}_{4}\right)(\mathrm{X}=\mathrm{Br}(2), \mathrm{I}(3))$, and (1,10-Hphen $)_{2}\left(\mathrm{HgX}_{4}\right)(\mathrm{X}$ $=\mathrm{Cl}(4), \mathrm{Br}(5)$, and I (6)), is reported, and their single-crystal $\mathrm{X}$-ray structures are determined. The study of their arrangements conjointly with periodic DFT calculations has enabled us to obtain more insight on the effect of these relatively unexplored cations with their corresponding halogen atom on the final packing and optoelectronic properties.

\section{RESULTS AND DISCUSSION}

Synthesis and General Characterization. All the reactions have been carried out by mixing $\operatorname{HgX}_{2}(\mathrm{X}=\mathrm{Cl}, \mathrm{Br}$, I) with $2,2^{\prime}$-bipyridine (2,2' -bipy) or 1,10-phenantroline (1,10phen) in a 1:2 molar ratio and acidified media with the corresponding acid $(\mathrm{HCl}, \mathrm{HBr}$, and $\mathrm{HI})$ in a $\mathrm{CH}_{2} \mathrm{Cl}_{2} / \mathrm{MeOH}$ solvent mixture at room temperature (r.t.). The $\mathrm{CH}_{2} \mathrm{Cl}_{2}$ / $\mathrm{MeOH}$ solvent mixtures were $2: 1(\mathbf{1}, \mathbf{2}, \mathbf{4}, \mathbf{5})$ or $1: 1(3,6)$, relying on the low solubility of $\mathrm{HgI}_{2}$ in $\mathrm{CH}_{2} \mathrm{Cl}_{2}$ (Scheme 1).

Scheme 1. Outline of the Synthesis of Compounds 1-6

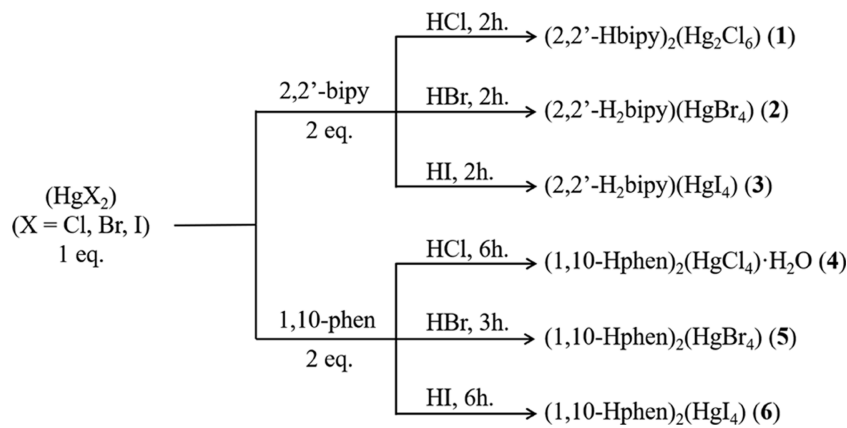

The formation of $2,2^{\prime}$-bipyridium $\left(2,2^{\prime} \text {-Hbipy }\right)^{+}, 2,2^{\prime}$ bipyridine-1, $1^{\prime}$-diium $\left(2,2^{\prime}-\mathrm{H}_{2} \text { bipy }\right)^{2+}$, or 1,10 -phenantrolinium $(1,10-\mathrm{Hphen})^{+}$cationic species resulted in compounds $\left(2,2^{\prime}-\mathrm{Hbipy}\right)_{2}\left(\mathrm{Hg}_{2} \mathrm{Cl}_{6}\right)(1),\left(2,2^{\prime}-\mathrm{H}_{2}\right.$ bipy $)\left(\mathrm{HgX}_{4}\right)(\mathrm{X}=\mathrm{Br}(2)$ and $\mathrm{I}(3))$, and $(1,10-\mathrm{Hphen})_{2}\left(\mathrm{HgX}_{4}\right)(\mathrm{X}=\mathrm{Cl}(4), \mathrm{Br}(5)$, and I (6)). All these compounds have been characterized by PXRD, EA, FTIR-ATR, and ${ }^{1} \mathrm{H}$ NMR spectroscopies; singlecrystal X-ray diffraction; and TG/DTA determination. It should be mentioned that even if the crystal structure of $\mathbf{2}$ was previously reported by $\mathrm{Ali}$ and $\mathrm{Al}-\mathrm{Far},{ }^{29}$ it was determined at $297 \mathrm{~K}$ rather than at $100 \mathrm{~K}$, which leads to slight changes in the unit cell and intermolecular interactions. In addition, the synthesis was performed using a different synthetic method.

Phase purity of the bulk samples was confirmed by PXRD (Supporting Information, Figure S1). In the FTIR-ATR spectra of 1-6, the $v\left(\mathrm{~N}-\mathrm{H}^{+}\right)$appeared as a broad band between 3448 and $2712 \mathrm{~cm}^{-1}$ and probably shifted to a minor wavenumber due to the strong ionic interaction between the proton and the corresponding halogen atom. ${ }^{30}$ This is reflected in the spectrum of compound 6 in which the $\mathrm{N}-\mathrm{H}^{+}$group is not hydrogen bonded to the $\left(\mathrm{HgI}_{4}\right)^{2-}$ anion and thus, the $v\left(\mathrm{~N}-\mathrm{H}^{+}\right)$peak is shifted to higher values. In addition, the formation of $\mathrm{C}-\mathrm{H} \cdots \mathrm{X}$ interactions provoked a redshift on the $v_{\mathrm{ar}}(\mathrm{C}-\mathrm{H})$ modes of the cations. Since the strength of these associations depend on the electronegativity of the acceptor, ${ }^{31}$ the shift is in line with the order $\mathrm{Cl}>\mathrm{Br}>\mathrm{I}$, ranging from 3094 to $3022 \mathrm{~cm}^{-1}$. The bands attributable to $v(\mathrm{C}=\mathrm{C} / \mathrm{C}=\mathrm{N})$ and $\delta\left(\mathrm{N}-\mathrm{H}^{+}\right)$appeared in the region between 1635 and 1443 $\mathrm{cm}^{-1}$, while $\delta(\mathrm{C}=\mathrm{C} / \mathrm{C}=\mathrm{N})$ ring modes ${ }^{32}$ appeared between 1428 and $1370 \mathrm{~cm}^{-1}$. The aromatic $\mathrm{C}-\mathrm{H}$ vibrational modes of the cations are also identified between 1185 and $1165 \mathrm{~cm}^{-1}$ $\left[\delta(\mathrm{C}-\mathrm{H})_{\mathrm{ip}}\right]$ or between 844 and $714 \mathrm{~cm}^{-1}\left[\delta(\mathrm{C}-\mathrm{H})_{\mathrm{oop}}\right]^{33}$ (Supporting Information, Figures S3-S8). An additional band from the $\gamma(\mathrm{N}-\mathrm{H})^{+}$out-of-plane mode ${ }^{30}$ is identified from 960 to $917 \mathrm{~cm}^{-1}$.

The ${ }^{1} \mathrm{H}$ NMR spectra of $\mathbf{1}-\mathbf{6}$ have been recorded in DMSO$d_{6}$ solution. They show four signals between 8.90 and 7.81 ppm (1-3) or between 9.32 and 8.18 ppm (4-6) assigned to the aromatic protons of the cations, which are shifted with respect to the free 2,2'-bipy and 1,10-phen molecules (8.68$7.44 \mathrm{ppm}$ and 9.10-7.76 ppm, respectively), indicating a change of the electronic distribution caused by the protonation of the corresponding $\mathrm{N}$-donor atoms. The $\mathrm{N}-\mathrm{H}^{+}$protons appear from 5.32-4.73 ppm in 1-3 and between 4.10-4.39 ppm in $4-6 .^{34}$ Further NMR details are provided in the Experimental Section (Supporting Information, Figures S9S14).

Finally, the TG/DTA determination of the samples enabled to analyze their thermal stability showing that they are stable until at least $220{ }^{\circ} \mathrm{C}$ (Supporting Information, Figure S15).

Crystal and Extended Structure of (2,2'-Hbipy) ${ }_{2}\left(\mathrm{Hg}_{2} \mathrm{Cl}_{6}\right)$ (1). Compound 1 is composed of a dimeric $\left(\mathrm{Hg}_{2} \mathrm{Cl}_{6}\right)^{2-}$ anion and two $\left(2,2^{\prime}-\mathrm{Hbipy}\right)^{+}$cations in cis conformation. The $\left(\mathrm{Hg}_{2} \mathrm{Cl}_{6}\right)^{2-}$ unit is formed around two $\mathrm{Hg}$ (II) centers at 3.8978 (4) $\AA$ (slightly longer than other reported $\mathrm{Hg} \cdots \mathrm{Hg}$ distances, 3.7523 (3)-3.884 (4) $\AA$ ), displaying a distorted tetrahedral geometry $\left(\tau_{4}(\mathrm{Hg}(1))=\right.$ $\left.0.80 ; \tau_{4}(\mathrm{Hg}(2))=0.72\right)^{35}$ and being connected through two asymmetrically bridging $\mathrm{Cl}$ and four terminal $\mathrm{Cl}$ atoms (Figure 1a). All the $\mathrm{Hg}-\mathrm{Cl}$ bond lengths fall within the range 2.3745 (9)-2.8758 (8) $\AA$ (Table 1), which are in accord with reported $\left(\mathrm{Hg}_{2} \mathrm{Cl}_{6}\right)^{2-}$ containing compounds (2.370 (2)-2.881 (2) $\AA) .{ }^{36-39}$

These dimeric units are held together in a linear fashion through the $a$ axis by interdimeric interactions between the $\mathrm{Hg}(\mathrm{II})$ centers and the terminal $\mathrm{Cl}(\mathrm{Hg}(2) \cdots \mathrm{Cl}(1), 3.1429$ (7) $\AA$ and $\mathrm{Hg}(1) \cdots \mathrm{Cl}(5), 3.3911$ (8) $\AA$ ) (being $3.30 \AA$ the sum of the van der Waals radii of both atoms). The $2,2^{\prime}$-Hbipy cations are disposed around these chains, being $\mathrm{N}-\mathrm{H}$ oriented to the remaining terminal $\mathrm{Cl}$ via hydrogen bond interactions. At both sides and parallel to the $\left(\mathrm{Hg}_{2} \mathrm{Cl}_{6}\right)^{2-}$ chain, the $2,2^{\prime}$ Hbipy cations are stacked through $\pi \cdots \pi$ interactions (Figure $1 b)$ in an alternate manner (double-single and so forth): double (pyridyl-pyridyl and pyridinium-pyridinium) and single (pyridyl-pyridyl) (Table 1 ). These $2,2^{\prime}$-Hbipy cations associate the chains forming a $3 \mathrm{D}$ net.

Crystal and Extended Structure of $\left(2,2^{\prime}-\mathrm{H}_{2}\right.$ bipy)$\left(\mathrm{HgBr}_{4}\right)$ (2). Compound 2 was previously reported ${ }^{29}$ by Ali and Al-Far, ${ }^{29}$ but we extended the structural study considering further interactions relevant for this paper. It is composed of one monomeric $\left(\mathrm{HgBr}_{4}\right)^{2-}$ anion and two $\left(2,2^{\prime}-\mathrm{H}_{2} \text { bipy }\right)^{2+}$ cations (Figure $2 \mathrm{a}$ ), in which the $\mathrm{Hg}$ (II) center displays a 
a)

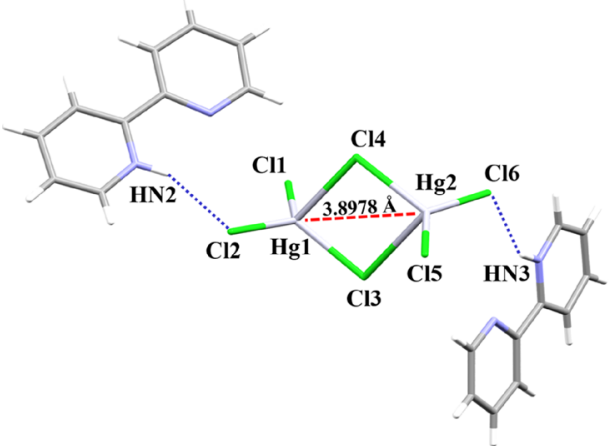

b)

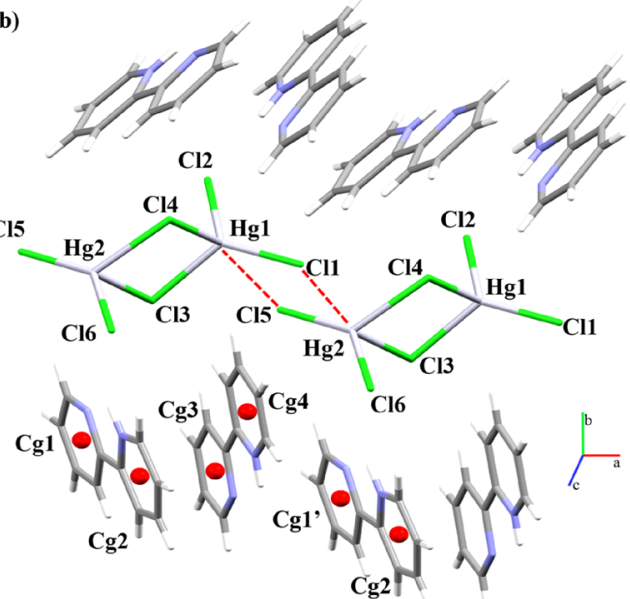

Figure 1. (a) Molecular structure of (2,2'-Hbipy $)_{2}\left(\mathrm{Hg}_{2} \mathrm{Cl}_{6}\right)$ (1) highlighting the ionic interactions between the 2,2'-Hbipy cations and the chlorine atoms. (b) $1 \mathrm{D}$ expansions of the dimeric units through $\mathrm{Hg} \cdots \mathrm{Cl}$ and $\pi \cdots \pi$ interactions.

slightly distorted tetrahedral geometry $\left(\tau_{4}(\mathrm{Hg}(1))=0.86\right){ }^{35}$ These anions are joined through ionic interactions into $1 \mathrm{D}$ chains along the $a$ axis via bridging $\operatorname{trans}\left(2,2^{\prime}-\mathrm{H}_{2} \text { bipy }\right)^{2+}$ (Figure $2 \mathrm{~b}$ ). It should be noted that there is an interaction between the $\mathrm{Br}$ (3) atom and the subsequent $\mathrm{Hg}$ (II) center of a contiguous monomeric unit at 3.5785 (5) A (longer than the sum of their van der Waals radii: $3.40 \AA$ ).

Even though it could not be considered a coordination bond, it is a non-negligible interaction since it directs the $\left(\mathrm{HgBr}_{4}\right)^{2-}$ stacking through the $c$ axis and lengthens the $\mathrm{Hg}$ (1) $-\mathrm{Br}(3)$ bond $(2.7985$ (5) $\AA$ ) compared to the rest $(2.5491$ (4) -2.6299 (4) $\AA$ ). All the $\mathrm{Hg}-\mathrm{Br}$ bond lengths are similar to the previously reported structure ${ }^{29}$ and within the range of other reported compounds with $\left(\mathrm{HgBr}_{4}\right)^{2-}$ anions and pyridinium cations $^{12}$ (2.6328 (4)-2.6900 (5) A) (Table 2). In this case, the $2,2^{\prime}-\mathrm{H}_{2}$ bipy rings are too far to assemble by $\pi \cdots \pi$ interactions (4.774 $\AA$ ) (Figure $2 \mathrm{~b}$ ).

Finally, the $2,2^{\prime}-\mathrm{H}_{2}$ bipy cations interact both supporting the stacking of the inorganic units via $\mathrm{C}-\mathrm{H} \cdots \mathrm{Br}$ interactions (C (4) $-\mathrm{H}(4) \cdots \mathrm{Br}(3), 2.9257 \AA$; $\mathrm{C}(7)-\mathrm{H}(7) \cdots \mathrm{Br}(1), 2.8372$

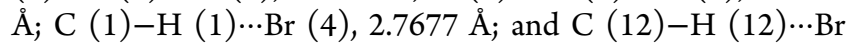
(4), $2.8960 \AA$ ) and joining the chains through $\mathrm{N}-\mathrm{H} \cdots \mathrm{Br}$ ionic associations $(\mathrm{N}(1)-\mathrm{H}(1 \mathrm{~N}) \cdots \mathrm{Br}(3), 2.3852 \AA$ and $\mathrm{N}(2)-\mathrm{H}$ $(2 \mathrm{~N}) \cdots \mathrm{Br}(2), 2.4593 \AA)$, which form a $2 \mathrm{D}$ layer along the $a c$ plane (Figure 2c) (Table 2).

Crystal and Extended Structure of $\left(2,2^{\prime}-\mathrm{H}_{2}\right.$ bipy $)\left(\mathrm{Hgl}_{4}\right)$ (3). Compound 3 is composed of a monomeric $\left(\mathrm{HgI}_{4}\right)^{2-}$ anion and two $\left(2,2^{\prime}-\mathrm{H}_{2} \text { bipy }\right)^{2+}$ cations. The $\mathrm{Hg}$ (II) center has a tetrahedral geometry $\left(\tau_{4}(\mathrm{Hg}(1))=0.94\right)^{35}$ (Figure 3a) (Table $3)$. These anions are discrete units without any significant interactions between them and surrounded by $\left(2,2^{\prime}-\mathrm{H}_{2} \text { bipy }\right)^{2+}$ cations through $\mathrm{N}-\mathrm{H} \cdots \mathrm{I}$ ionic associations $(\mathrm{N}(1)-\mathrm{H}(1 \mathrm{~N}) \cdots \mathrm{I}$ (2), $2.6524 \AA$ and $\mathrm{N}(2)-\mathrm{H}(2 \mathrm{~N}) \cdots \mathrm{I}(1), 2.5764 \AA$ ) and weak $\mathrm{C}-\mathrm{H} \cdots \mathrm{I}$ interactions, which form linear zigzag chains along the $b$ axis (Figure $3 \mathrm{~b}$ ) (Table 3 ). The $\mathrm{Hg}-\mathrm{I}$ bond lengths $(2.7398$ (5) -2.8398 (5) $\AA$ ) are within the range of reported $\left(\mathrm{HgI}_{4}\right)^{2-}$ anions $\left(2.7430(8)-2.844\right.$ (1) Å). ${ }^{40-42}$

Only weak reciprocal $\mathrm{C}-\mathrm{H} \cdot \cdots \mathrm{I}$ contacts join the chains along the $c$ axis $(\mathrm{C}(8)-\mathrm{H}(8) \cdots \mathrm{I}(4), 3.1363 \AA$ and $\mathrm{H}(8)-\mathrm{C}(8) \cdots \mathrm{I}$ (4), 3.895 (7) $\left.\AA ; 138.10^{\circ}\right)$, defining $2 \mathrm{D}$ layers through the $b c$ plane and as in the case of $2,\left(2,2^{\prime}-\mathrm{H}_{2} \text { bipy }\right)^{2+}$ cations are too far to be stacked trough $\pi \cdots \pi$ interactions (4.360 $)$.
Crystal and Extended Structure of $(1,10$ Hphen $)_{2}\left(\mathrm{HgX}_{4}\right)(\mathrm{X}=\mathrm{Cl}(4), \mathrm{Br}(5)$, or I (6)). Compounds 4-6 are composed of $\left(\mathrm{HgX}_{4}\right)^{2-}(\mathrm{X}=\mathrm{Cl}(4), \mathrm{Br}(5)$, or I (6)) anions and 1,10-Hphen cations mainly associated through $\mathrm{N}-$ $\mathrm{H} \cdots \mathrm{X}, \mathrm{N}-\mathrm{H} \cdots \mathrm{O}$, and $\mathrm{C}-\mathrm{H} \cdots \mathrm{X}$ interactions (Figure 4). In the three compounds, the monomeric $\mathrm{Hg}$ (II) centers display a slightly distorted tetrahedral geometry $\left(4: \tau_{4}(\mathrm{Hg}(1))=0.92\right.$; 5: $\left.\tau_{4}(\mathrm{Hg}(1))=0.91 ; 6: \tau_{4}(\mathrm{Hg}(1))=0.95\right) .{ }^{35}$ The $\mathrm{Hg}-\mathrm{X}$ bond lengths are within the range of reported $\left(\mathrm{HgX}_{4}\right)^{2-}$ anions $^{12,36-42}$ (Table 4).

In 4, each $\mathrm{Hg}(\mathrm{II})$ node interacts with two $(1,10-\mathrm{Hphen})^{+}$ cations either directly $\mathrm{N}(2)-\mathrm{H}(2 \mathrm{~N}) \cdots \mathrm{Cl}(2)(2.4169 \AA)$ or through a water molecule $\mathrm{N}(4)-\mathrm{H}(4 \mathrm{~N}) \cdots \mathrm{O}(1.855 \AA)$ and $\mathrm{O}(1 \mathrm{~W})-\mathrm{H}(1 \mathrm{WB}) \cdots \mathrm{Cl}$ (4) (2.375 (2) ̊) (Table 5). This double association alters the intermolecular interactions, forming zigzag 1D chains along the $c$ axis (Figure 5a).

In two previously reported closely related case studies, the mono- or diprotonated 1,10-phenantrolines in (phenH) $)_{2}\left[\mathrm{ZnCl}_{4}\right] \cdot \mathrm{H}_{2} \mathrm{O}$ or $\left(\mathrm{phenH}_{2}\right)_{2} \mathrm{~Pb}_{3} \mathrm{I}_{10} \cdot 2 \mathrm{H}_{2} \mathrm{O}$ also interact through water molecules rather than directly with the corresponding halogen atoms. ${ }^{2,43}$ There are precedents demonstrating the strength of the $\mathrm{Cl} \cdots \mathrm{H}_{2} \mathrm{O}$ interaction. ${ }^{44}$ In addition, $\left(\mathrm{HgCl}_{4}\right)^{2-}$ anions are surrounded by six $(1,10-$ Hphen $)^{+}$cations stacked in pairs by reciprocal $\pi \cdots \pi$ interactions (Figure $5 \mathrm{~b}$ ) and associated with the anion via combination of $\mathrm{C}-\mathrm{H} \cdots \mathrm{Cl}$ and $\mathrm{N}-\mathrm{H} \cdots \mathrm{Cl}$. In addition, these cations are weakly interacting with neighboring anions by $\mathrm{Cl} \cdots \pi^{4,5}$ (Figure 5c), which form a 3D net.

In 5, two $(1,10-\mathrm{Hphen})^{+}$cations associate with a $\left(\mathrm{HgBr}_{4}\right)^{2-}$ anion through double $\mathrm{N}-\mathrm{H} \cdots \mathrm{Br}$ and $\mathrm{C}-\mathrm{H} \cdots \mathrm{Br}$ interactions within the range of similar compounds ${ }^{12}$ (Table 6). In addition, these anions are surrounded by $(1,10-\mathrm{Hphen})^{+}$ cations disposed in five pairs stacked by double (Figure 6a) or triple (Figure $6 \mathrm{~b}$ ) $\pi \cdots \pi$ interactions and a weak $\mathrm{Br} \cdots \pi$ contact $^{4,5}$ (Figure 6c). These planar associations hold together the $(1,10-\mathrm{Hphen})_{2}\left(\mathrm{HgBr}_{4}\right)$ assemblies, forming a $3 \mathrm{D}$ net.

In 6 , the structural disorder limits the analysis of the intermolecular interactions; however, $\mathrm{N}$ atoms are too far from the $\mathrm{I}$ and thus, there is not any $\mathrm{N}-\mathrm{H} \cdots \mathrm{I}$ interaction. Instead, the $\left(\mathrm{HgI}_{4}\right)^{2-}$ anions associate through $\mathrm{C}-\mathrm{H} \cdots \mathrm{I}$ interactions with eight $(1,10-\text { Hphen })^{+}$cations (Figure $\left.7 \mathrm{a}\right)$, which are stacked in chains by reciprocals pyridinium-phenyl $\pi \cdots \pi$ interactions (Table 7) along the $a$ axis in a piled disposition 
Table 1. Selected Bond Lengths, Angles, and Intermolecular Interactions of $\left(2,2^{\prime}-\mathrm{Hbipy}\right)_{2}\left(\mathrm{Hg}_{2} \mathrm{Cl}_{6}\right)(1)^{a}$

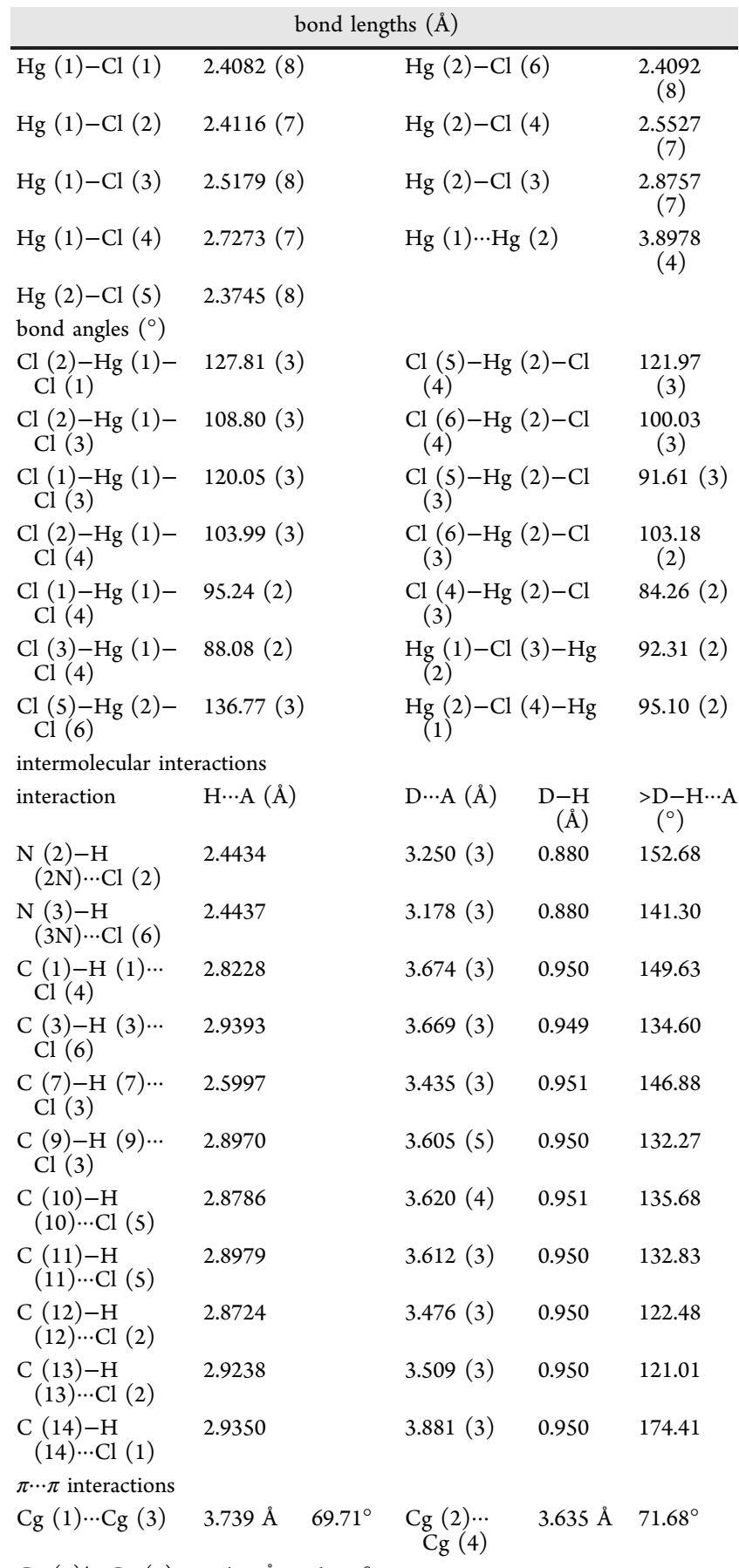

$\mathrm{Cg}(1)^{\prime} \cdots \mathrm{Cg}(3) \quad 3.653 \AA \quad 67.98^{\circ}$

${ }^{a} \mathrm{Cg}(1)=\mathrm{Cg}(1)^{\prime}: \mathrm{N} 1-\mathrm{C} 1-\mathrm{C} 2-\mathrm{C} 3-\mathrm{C} 4-\mathrm{C} 5 ; \mathrm{Cg}(2): \mathrm{N} 2-\mathrm{C} 6-$ $\mathrm{C} 7-\mathrm{C} 8-\mathrm{C} 9-\mathrm{C} 10 ; \mathrm{Cg}$ (3): N4-C16-C17-C18-C19-C20; Cg (4): N3-C11-C12-C13-C14-C15.

(Figure $7 \mathrm{~b}$ ). These chains are held together by the anions forming a 3D net.

Packing Analysis of 1-6. General Considerations. Some remarks should be examined to better comprehend these structural arrangements. We will emphasize the role of the halogen atoms (regarding their electronegativities, radii, and polarizabilities) and the organic units (planarity, mono- or diprotonation, and thus, their different electronic density distributions). Noteworthy is the increased role of weak a)

c)

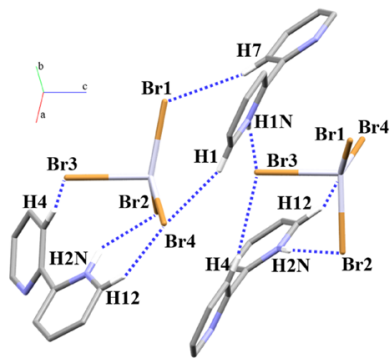

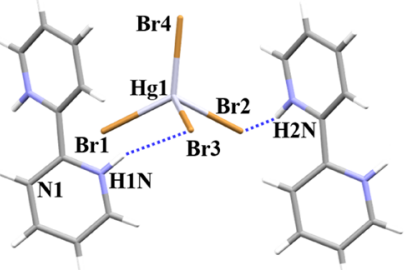

b)

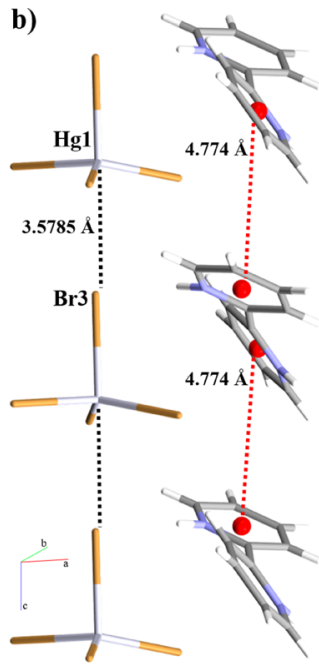

Figure 2. (a) Molecular structure of $\left(2,2^{\prime}-\mathrm{H}_{2}\right.$ bipy $)\left(\mathrm{HgBr}_{4}\right)$ (2) highlighting the ionic interactions between the $2,2^{\prime}-\mathrm{H}_{2}$ bipy cations and the bromine atoms. (b) Linear $\mathrm{Br} \cdots \mathrm{Hg}$ associations and (c) intermolecular interactions between $\left(2,2^{\prime}-\mathrm{H}_{2} \mathrm{Bipy}\right)^{2+}$ and $\mathrm{Br}$ atoms.

Table 2. Selected Bond Lengths, Angles, and Intermolecular Interactions of $\left(2,2^{\prime}-\mathrm{H}_{2}\right.$ bipy $)\left(\mathrm{HgBr}_{4}\right)(2)$

\begin{tabular}{|c|c|c|c|c|}
\hline \multicolumn{5}{|c|}{ bond lengths $(\AA)$} \\
\hline $\mathrm{Hg}(1)-\mathrm{Br}(1)$ & $2.4082(8)$ & \multicolumn{2}{|c|}{$\mathrm{Hg}(1)-\mathrm{Br}(4)$} & $2.7273(7)$ \\
\hline $\mathrm{Hg}(1)-\mathrm{Br}(2)$ & $2.4116(7)$ & \multicolumn{2}{|c|}{$\mathrm{Hg}(1) \cdots \mathrm{Br}(3)$} & $3.5785(5)$ \\
\hline $\mathrm{Hg}(1)-\mathrm{Br}(3)$ & $2.5179(8)$ & & & \\
\hline \multicolumn{5}{|l|}{ bond angles $\left({ }^{\circ}\right)$} \\
\hline $\begin{array}{l}\mathrm{Br}(4)-\mathrm{Hg}(1)-\mathrm{Br} \\
\quad(1)\end{array}$ & $\begin{array}{c}122.503 \\
(11)\end{array}$ & \multicolumn{2}{|c|}{$\begin{array}{l}\mathrm{Br}(4)-\mathrm{Hg}(1)-\mathrm{Br} \\
\text { (3) }\end{array}$} & $102.176(10)$ \\
\hline $\begin{array}{l}\mathrm{Br}(4)-\mathrm{Hg}(1)-\mathrm{Br} \\
\quad \text { (2) }\end{array}$ & $\begin{array}{l}114.042 \\
(11)\end{array}$ & \multicolumn{2}{|c|}{$\begin{array}{l}\mathrm{Br}(1)-\mathrm{Hg}(1)-\mathrm{Br} \\
\text { (3) }\end{array}$} & $101.330(11)$ \\
\hline $\begin{array}{l}\mathrm{Br}(1)-\mathrm{Hg}(1)-\mathrm{Br} \\
\quad(2)\end{array}$ & $\begin{array}{c}116.734 \\
(13)\end{array}$ & \multicolumn{2}{|c|}{$\begin{array}{l}\mathrm{Br}(2)-\mathrm{Hg}(1)-\mathrm{Br} \\
\text { (3) }\end{array}$} & $91.901(10)$ \\
\hline \multicolumn{5}{|c|}{ intermolecular interactions } \\
\hline interaction & $\mathrm{H} \cdots \mathrm{A}(\AA)$ & $\begin{array}{r}\mathrm{D} \cdots \mathrm{A} \\
(\AA)\end{array}$ & $\underset{(\AA)}{\mathrm{D}-\mathrm{H}}$ & $\begin{array}{l}>\mathrm{D}-\mathrm{H} \cdots \mathrm{A} \\
\left(^{\circ}\right)\end{array}$ \\
\hline $\begin{array}{l}\mathrm{N}(1)-\mathrm{H}(1 \mathrm{~N}) \cdots \mathrm{Br} \\
(3)\end{array}$ & 2.3852 & $3.202(3)$ & 0.880 & 154.53 \\
\hline $\begin{array}{l}\mathrm{N}(2)-\mathrm{H}(2 \mathrm{~N}) \cdots \mathrm{Br} \\
\quad(2)\end{array}$ & 2.4593 & $3.276(3)$ & 0.880 & 154.60 \\
\hline $\mathrm{C}(1)-\mathrm{H}(1) \cdots \mathrm{Br}(4)$ & 2.7677 & $3.673(4)$ & 0.950 & 159.61 \\
\hline $\mathrm{C}(2)-\mathrm{H}(2) \cdots \mathrm{Br}(1)$ & 2.9689 & $3.800(4)$ & 0.951 & 146.85 \\
\hline $\mathrm{C}(4)-\mathrm{H}(4) \cdots \mathrm{Br}(3)$ & 2.9257 & $3.830(3)$ & 0.950 & 159.50 \\
\hline $\mathrm{C}(7)-\mathrm{H}(7) \cdots \mathrm{Br}(1)$ & 2.8372 & $3.751(4)$ & 0.950 & 132.27 \\
\hline $\mathrm{C}(8)-\mathrm{H}(8) \cdots \mathrm{Br}(3)$ & 2.9803 & $3.653(3)$ & 0.949 & 128.98 \\
\hline $\begin{array}{l}\mathrm{C}(11)-\mathrm{H}(11) \cdots \mathrm{Br} \\
\quad(2)\end{array}$ & 2.9828 & $3.834(4)$ & 0.950 & 149.89 \\
\hline $\begin{array}{l}\mathrm{C}(12)-\mathrm{H}(12) \cdots \mathrm{Br} \\
\quad(4)\end{array}$ & 2.8960 & $3.789(4)$ & 0.950 & 157.08 \\
\hline
\end{tabular}

hydrogen bonds (WHB). ${ }^{9}$ Despite being considered secondary interactions, the formation of the cations is deemed responsible to increase the hydrogen donor propensity of the aromatic $\mathrm{C}-\mathrm{H}$ groups, thus promoting the formation of $\mathrm{C}-$ $\mathrm{H} \cdots \mathrm{X}(\mathrm{X}=\mathrm{Cl}, \mathrm{Br}$, or I $)$ interactions. Likewise, it facilitated the formation of $\mathrm{X} \cdots \pi$ interactions instead of $\mathrm{C}-\mathrm{H} \cdots \pi$ associations. All of them arise as determining factors in the structural analysis.

The essential interactions will be divided into three groups: $\mathrm{N}-\mathrm{H} / \mathrm{C}-\mathrm{H} \cdots \mathrm{X}, \mathrm{X} \cdots \mathrm{Hg}(\mathrm{II})$, and planar $\pi \cdots \pi$ interactions. For the sake of analyzing them, Hirshfeld surfaces with their $2 \mathrm{D}$ 
a)

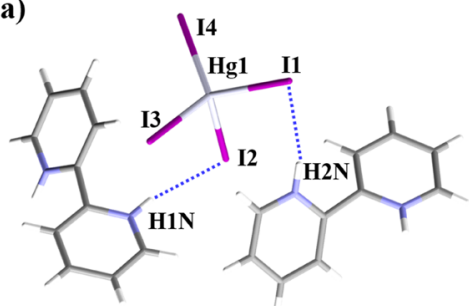

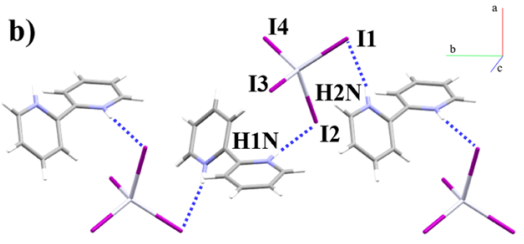

Figure 3. (a) Molecular structure of $\left(2,2^{\prime}-\mathrm{H}_{2}\right.$ bipy $)\left(\mathrm{HgI}_{4}\right)$ (3) highlighting the ionic interactions between the $2,2^{\prime}-\mathrm{H}_{2}$ bipy cations and the iodine atoms and (b) 1D zigzag association through the $b$ axis.

Table 3. Selected Bond Lengths, Angles and Intermolecular Interactions of $\left(2,2^{\prime}-\mathrm{H}_{2}\right.$ bipy $)\left(\mathrm{HgI}_{4}\right)$ (3)

\begin{tabular}{|c|c|c|c|c|}
\hline \multicolumn{5}{|c|}{ bond lengths $(\AA)$} \\
\hline $\mathrm{Hg}(1)-\mathrm{I}(1)$ & $2.8032(4)$ & \multicolumn{2}{|c|}{$\mathrm{Hg}(1)-\mathrm{I}(3)$} & $2.7756(5)$ \\
\hline $\mathrm{Hg}(1)-\mathrm{I}(2)$ & $2.8398(5)$ & \multicolumn{2}{|c|}{$\mathrm{Hg}(1)-\mathrm{I}(4)$} & $2.7483(4)$ \\
\hline \multicolumn{5}{|l|}{ bond angles $\left({ }^{\circ}\right)$} \\
\hline $\mathrm{I}(4)-\mathrm{Hg}(1)-\mathrm{I}(3)$ & $\begin{array}{c}116.276 \\
(14)\end{array}$ & \multicolumn{2}{|c|}{$\mathrm{I}(4)-\mathrm{Hg}(1)-\mathrm{I}(2)$} & $111.799(14)$ \\
\hline $\mathrm{I}(4)-\mathrm{Hg}(1)-\mathrm{I}(1)$ & $\begin{array}{c}108.793 \\
(14)\end{array}$ & \multicolumn{2}{|c|}{$\mathrm{I}(3)-\mathrm{Hg}(1)-\mathrm{I}(2)$} & $100.591(14)$ \\
\hline $\mathrm{I}(3)-\mathrm{Hg}(1)-\mathrm{I}(1)$ & $\begin{array}{c}111.401 \\
(14)\end{array}$ & \multicolumn{2}{|c|}{$\mathrm{I}(1)-\mathrm{Hg}(1)-\mathrm{I}(2)$} & $107.493(13)$ \\
\hline \multicolumn{5}{|c|}{ intermolecular interactions } \\
\hline interaction & $\mathrm{H} \cdots \mathrm{A}(\AA)$ & $\mathrm{D} \cdots \mathrm{A}(\AA)$ & $\mathrm{D}-\mathrm{H}(\AA)$ & $\begin{array}{l}>\mathrm{D}-\mathrm{H} \cdots \mathrm{A} \\
\left({ }^{\circ}\right)\end{array}$ \\
\hline $\begin{array}{l}\mathrm{N}(1)-\mathrm{H}(1 \mathrm{~N}) \cdots \mathrm{I} \\
(2)\end{array}$ & 2.6524 & $3.486(5)$ & 0.880 & 158.38 \\
\hline $\begin{array}{l}\mathrm{N}(2)-\mathrm{H}(2 \mathrm{~N}) \cdots \mathrm{I} \\
(1)\end{array}$ & 2.5764 & $3.434(5)$ & 0.880 & 165.99 \\
\hline $\mathrm{C}(4)-\mathrm{H}(4) \cdots \mathrm{I}(2)$ & 3.1783 & $4.022(6)$ & 0.950 & 149.05 \\
\hline $\mathrm{C}(7)-\mathrm{H}(7) \cdots \mathrm{I}(3)$ & 3.1264 & $3.977(6)$ & 0.950 & 149.87 \\
\hline $\mathrm{C}(8)-\mathrm{H}(8) \cdots \mathrm{I}(4)$ & 3.1363 & $3.895(7)$ & 0.950 & 138.10 \\
\hline $\mathrm{C}(9)-\mathrm{H}(9) \cdots \mathrm{I}(2)$ & 3.1407 & $3.976(6)$ & 0.950 & 147.66 \\
\hline
\end{tabular}

fingerprint plots and 3D deformation density (DD) maps have been generated using CrystalExplorer 17.5. ${ }^{45}$ The DD
Table 4. Selected Bond Lengths and Angles of $(1,10$ Hphen $)_{2}\left(\mathrm{HgCl}_{4}\right) \cdot \mathrm{H}_{2} \mathrm{O}(4),(1,10-\mathrm{Hphen})\left(\mathrm{HgBr}_{4}\right)(5)$, and $\left(1,10-H_{p h e n}\right)\left(\mathrm{HgI}_{4}\right)(6)^{a}$

\begin{tabular}{|c|c|c|c|}
\hline 4 & \multicolumn{3}{|c|}{ bond lengths $(\AA)$} \\
\hline $\mathrm{Hg}(1)-\mathrm{Cl}(1)$ & $2.4412(5)$ & $\mathrm{Hg}(1)-\mathrm{Cl}(3)$ & $2.4803(4)$ \\
\hline $\mathrm{Hg}(1)-\mathrm{Cl}(2)$ & $2.5452(5)$ & $\mathrm{Hg}(1)-\mathrm{Cl}(4)$ & $2.4952(5)$ \\
\hline \multicolumn{4}{|l|}{ bond angles $\left({ }^{\circ}\right)$} \\
\hline $\begin{array}{l}\mathrm{Cl}(1)-\mathrm{Hg}(1)- \\
\mathrm{Cl}(3)\end{array}$ & $115.258(15)$ & $\begin{array}{l}\mathrm{Cl}(1)-\mathrm{Hg}(1)-\mathrm{Cl} \\
\quad(2)\end{array}$ & $107.685(16)$ \\
\hline $\begin{array}{l}\mathrm{Cl}(1)-\mathrm{Hg}(1)- \\
\mathrm{Cl}(4)\end{array}$ & $115.283(18)$ & $\begin{array}{l}\mathrm{Cl}(3)-\mathrm{Hg}(1)-\mathrm{Cl} \\
\quad(2)\end{array}$ & $102.096(15)$ \\
\hline $\begin{array}{l}\mathrm{Cl}(3)-\mathrm{Hg}(1)- \\
\mathrm{Cl}(4)\end{array}$ & $108.624(16)$ & $\begin{array}{l}\mathrm{Cl}(4)-\mathrm{Hg}(1)-\mathrm{Cl} \\
\quad(2)\end{array}$ & $106.723(18)$ \\
\hline 5 & \multicolumn{3}{|c|}{ bond lengths $(\AA)$} \\
\hline $\mathrm{Hg}(1)-\mathrm{Br}(1)$ & $2.5594(10)$ & $\mathrm{Hg}(1)-\mathrm{Br}(3)$ & $2.4512(11)$ \\
\hline $\mathrm{Hg}(1)-\mathrm{Br}(2)$ & $2.4486(11)$ & $\mathrm{Hg}(1)-\mathrm{Br}(4)$ & $2.5221(11)$ \\
\hline \multicolumn{4}{|l|}{ bond angles $\left({ }^{\circ}\right)$} \\
\hline $\begin{array}{l}\mathrm{Br}(2)-\mathrm{Hg}(1)- \\
\quad \mathrm{Br}(3)\end{array}$ & $120.59(4)$ & $\begin{array}{l}\mathrm{Br}(2)-\mathrm{Hg}(1)-\mathrm{Br} \\
\quad \text { (1) }\end{array}$ & $108.55(4)$ \\
\hline $\begin{array}{l}\mathrm{Br}(2)-\mathrm{Hg}(1)- \\
\quad \mathrm{Br}(4)\end{array}$ & $110.75(4)$ & $\begin{array}{l}\mathrm{Br}(3)-\mathrm{Hg}(1)-\mathrm{Br} \\
\quad \text { (1) }\end{array}$ & $104.78(4)$ \\
\hline $\begin{array}{l}\mathrm{Br}(3)-\mathrm{Hg}(1)- \\
\mathrm{Br}(4)\end{array}$ & $108.41(4)$ & $\begin{array}{l}\mathrm{Br}(4)-\mathrm{Hg}(1)-\mathrm{Br} \\
\quad \text { (1) }\end{array}$ & $102.02(4)$ \\
\hline 6 & \multicolumn{3}{|c|}{ bond lengths $(\AA)$} \\
\hline $\begin{array}{l}\mathrm{Hg}(1)-\mathrm{I}(1) \# 1 \\
\text { bond angles }\left({ }^{\circ}\right)\end{array}$ & $2.7760(9)$ & $\mathrm{Hg}(1)-\mathrm{I}(2) \# 1$ & $2.7737(9)$ \\
\hline $\begin{array}{l}\text { I }(2)-H g(1)-I \\
\text { (2) \#1 }\end{array}$ & $113.27(4)$ & $\begin{array}{l}\text { I (2)\#1-Hg (1)-I } \\
\quad(1) \# 1\end{array}$ & $105.36(2)$ \\
\hline $\begin{array}{l}\text { I } \underset{(1)}{(2)}-\mathrm{Hg}(1)-\mathrm{I} \\
\text { (1) }\end{array}$ & $109.83(2)$ & $\begin{array}{l}\mathrm{I}(1) \# 1-\mathrm{Hg}(1)-\mathrm{I} \\
\quad(1)\end{array}$ & $113.36(4)$ \\
\hline
\end{tabular}

isosurfaces of $1-5$ are drawn at $0.008 \mathrm{eau}^{-3}$, and their wave functions were calculated by the density functional theory (DFT) at the 6-311++G(2d,2p) level with Becke 88 gradientcorrected exchange and LYP correlation energy functional ${ }^{46}$ using TONTO. Unfortunately, the structural disorder of compound $\mathbf{6}$ has excluded it from this calculation.

The DD mapping allows the representation of electronic density distribution along the molecule after suffering the polarization because of the interactions in which it participates. Low electron density areas termed charge depletion (CD) regions can attractively interact with charge concentration (CC) areas which are more electron rich. In this sense, univalent halogen atoms can be polarized upon coordination and generate a CD region named $\sigma$-hole ${ }^{6,7}$ on the extension of the bond and thus more electron-rich regions at the sides. a)

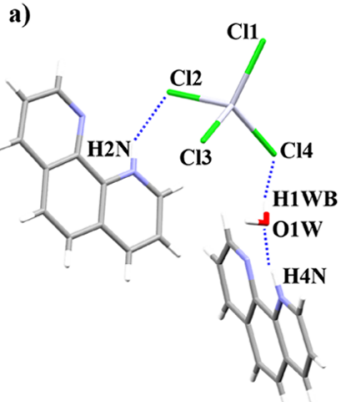

b)

b)

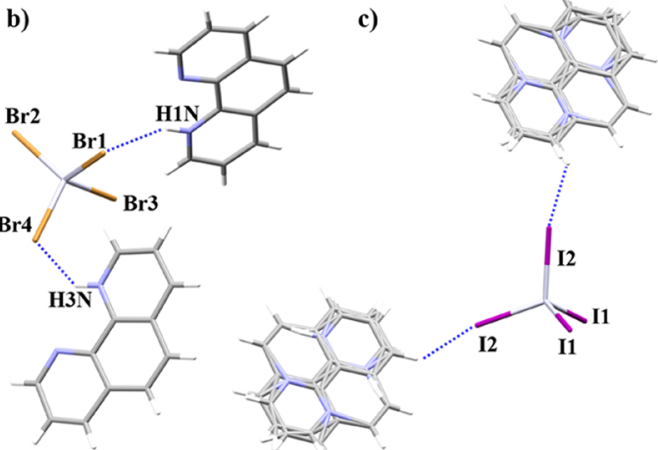

Figure 4. Molecular structure of $(1,10-\mathrm{Hphen})_{2}\left(\mathrm{HgX}_{4}\right)(\mathrm{X}=(\mathrm{a}) \mathrm{Cl}(4),(\mathrm{b}) \mathrm{Br}(5)$, or (c) I (6)) highlighting the closer interactions between the 1,10-Hphen cations and the halogen atoms. 
Table 5. Intermolecular Interactions of $(1,10-$ Hphen $)_{2}\left(\mathrm{HgCl}_{4}\right) \cdot \mathrm{H}_{2} \mathrm{O}(4)^{a}$

\begin{tabular}{|c|c|c|c|c|}
\hline interaction & $\mathrm{H} \cdots \mathrm{A}(\AA)$ & $\mathrm{D} \cdots \mathrm{A}(\AA)$ & D-H $(\AA)$ & $\begin{array}{c}>\mathrm{D}-\mathrm{H} \cdots \mathrm{A} \\
\left({ }^{\circ}\right)\end{array}$ \\
\hline $\begin{array}{l}\mathrm{N}(2)-\mathrm{H}(2 \mathrm{~N}) \cdots \mathrm{Cl} \\
(2)\end{array}$ & 2.4169 & $3.200(2)$ & 0.880 & 148.44 \\
\hline $\begin{array}{l}\mathrm{N}(4)-\mathrm{H}(4 \mathrm{~N}) \cdots \mathrm{O}(1 \\
\mathrm{W})\end{array}$ & 1.855 & $2.683(2)$ & 0.880 & 155.87 \\
\hline $\begin{array}{l}\mathrm{O}(1 \mathrm{~W})-\mathrm{H}(1 \mathrm{WB}) \cdots \\
\quad \mathrm{Cl}(4)\end{array}$ & $2.375(2)$ & $3.171(1)$ & $0.803(2)$ & 171.16 \\
\hline $\mathrm{C}(2)-\mathrm{H}(2) \cdots \mathrm{Cl}(1)$ & 2.7057 & $3.576(2)$ & 0.950 & 152.60 \\
\hline $\mathrm{C}(3)-\mathrm{H}(3) \cdots \mathrm{Cl}(3)$ & 2.7647 & $3.661(2)$ & 0.950 & 157.57 \\
\hline $\begin{array}{l}\mathrm{C}(13)-\mathrm{H}(13) \cdots \mathrm{Cl} \\
(4)\end{array}$ & 2.8201 & $3.461(2)$ & 0.950 & 125.62 \\
\hline $\begin{array}{l}\mathrm{C}(14)-\mathrm{H}(14) \cdots \mathrm{Cl} \\
(2)\end{array}$ & 2.9070 & $3.647(2)$ & 0.950 & 135.66 \\
\hline $\begin{array}{l}\mathrm{C}(18)-\mathrm{H}(18) \cdots \mathrm{Cl} \\
\quad(1)\end{array}$ & 2.7230 & $3.669(2)$ & 0.950 & 173.71 \\
\hline $\begin{array}{l}\mathrm{C}(21)-\mathrm{H}(21) \cdots \mathrm{Cl} \\
(4)\end{array}$ & 2.9302 & $3.727(2)$ & 0.950 & 142.24 \\
\hline \multicolumn{5}{|l|}{$\pi \cdots \pi$ interactions } \\
\hline $\mathrm{Cg}(1) \cdots \mathrm{Cg}(2)$ & \multicolumn{2}{|l|}{$3.685 \AA$} & \multicolumn{2}{|l|}{$68.06^{\circ}$} \\
\hline $\mathrm{Cg}(3) \cdots \mathrm{Cg}(4)$ & \multicolumn{2}{|l|}{$3.593 \AA$} & \multicolumn{2}{|l|}{$77.33^{\circ}$} \\
\hline \multicolumn{5}{|c|}{$\begin{array}{l}{ }^{a} \mathrm{Cg}(1): \mathrm{C} 4-\mathrm{C} 5-\mathrm{C} 6-\mathrm{C} 7-\mathrm{C} 11-\mathrm{C} 12 ; \mathrm{Cg}(2): \mathrm{N} 1-\mathrm{C} 1-\mathrm{C} 2-\mathrm{C} 3- \\
\mathrm{C} 4-\mathrm{C} 12 ; \mathrm{Cg}(3): \mathrm{N} 4-\mathrm{C} 17-\mathrm{C} 18-\mathrm{C} 19-\mathrm{C} 20-\mathrm{C} 21 ; \mathrm{Cg}(4): \mathrm{C} 16- \\
\mathrm{C} 17-\mathrm{C} 20-\mathrm{C} 22-\mathrm{C} 23-\mathrm{C} 24 .\end{array}$} \\
\hline
\end{tabular}

Structures Containing $\left(2,2^{\prime}-\mathrm{Hbipy}\right)^{+}$or $\left(2,2^{\prime}-\mathrm{H}_{2} \text { bipy }\right)^{2+}$ $(1-3)$. The $\mathrm{N}-\mathrm{H} \cdots \mathrm{X}$ contacts hold together these arrays being the strongest interactions, subsequently supported by $\mathrm{C}-\mathrm{H} \cdots \mathrm{X}$ associations. Their Hirshfeld surfaces outline these contacts, and the shorter $\mathrm{N}-\mathrm{H} \cdots \mathrm{X}$ interactions are represented as sharp peaks in the 2D fingerprint plots (Figure 8).
The percentages of the surface area implied in these interactions are 31.5 and 28.8 (1), 42.6 (2), and 50.1 (3), being the greatest values compared to the rest (Table 8 ). The size of the halogen atoms and proximity to the cations are the main contributors; hence, even if $\mathbf{3}$ has a bigger percentage, the position of the peaks in the $2 \mathrm{D}$ fingerprint plots reflects the larger distances and thus weaker interactions between the inner hydrogens of the surface and the closest outer I atom.

The DD mapping of $\left(2,2^{\prime}-\mathrm{Hbipy}\right)^{+}(\mathbf{1})$ and $\left(2,2^{\prime}-\mathrm{H}_{2} \text { bipy }\right)^{2+}$ (2 and 3) displays large CD regions extended throughout the rings promoted by their protonation and the interactions with the surrounding atoms (Figure 9). Within this frame, the tendency of halogen atoms of being oriented through a side, perpendicular to the extension of the bond when they interact with $\mathrm{CD}$ regions, or through the extension of the bond when they associate to CC regions, suggests the presence of $\sigma$-hole interactions. It is worth mentioning a haptic-like interaction ${ }^{2}$ between the face of the $\left(\mathrm{HgI}_{4}\right)^{2-}$ tetrahedra and the pyridyl ring of the $\left(2,2^{\prime} \mathrm{H}_{2} \text { bipy }\right)^{2+}$ cation (Figure $9 \mathrm{c}$ ), which could facilitate charge transfers (CTs) between them.

For what concerns the $\mathrm{X} \cdots \mathrm{Hg}(\mathrm{II})$ interactions, they have modified the nuclearity and association of inorganic anions between themselves, forming strong linear associated dimeric arrays (1), weak linear associated monomers (2), or discrete monomers assembled by cations in a zigzag fashion (3). Their 2D fingerprint displays small sharp peaks that decrease until disappearance from $\mathrm{Cl}$ to $\mathrm{I}$, and the surface percentage between the halogen atoms and the $\mathrm{Hg}$ (II) centers being 3.8 (1), 1.8 (2), and 0.2 (3) thereby confirms the aforementioned tendency. Likewise, the distortion of the $\left(\mathrm{HgX}_{4}\right)^{2-}(\mathrm{X}=\mathrm{Cl}, \mathrm{Br}$, or I) geometry is directly correlated to the strength of the interactions between the inorganic units in the order $\mathrm{Cl}>\mathrm{Br}>$ I (Figure 8).

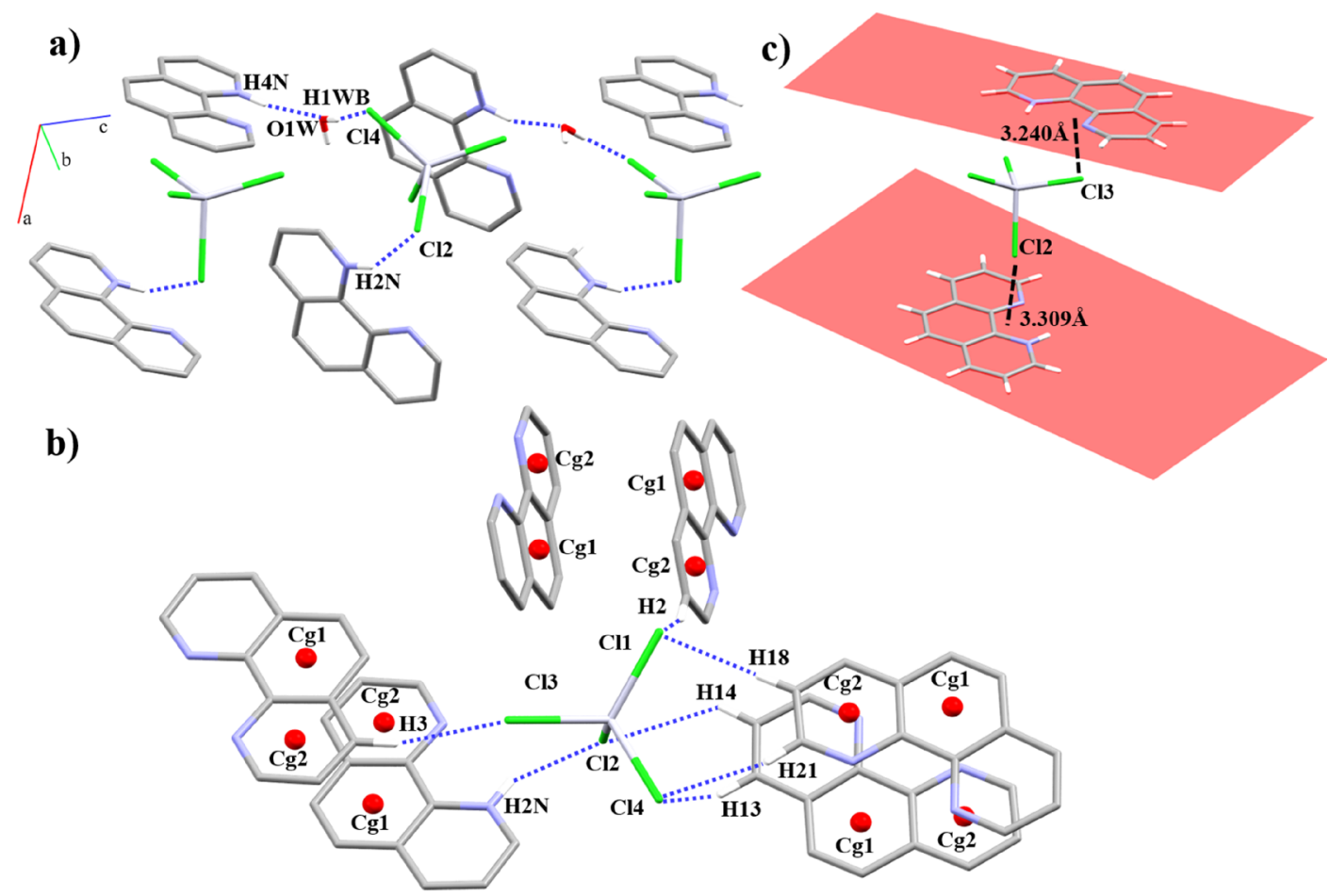

Figure 5. Intermolecular interactions of $(1,10-\mathrm{Hphen})_{2}\left(\mathrm{HgCl}_{4}\right) \cdot \mathrm{H}_{2} \mathrm{O}$ (4). (a) Zigzag chains formed through $\mathrm{N}-\mathrm{H} \cdots \mathrm{Cl}$ and $\mathrm{N}-\mathrm{H} \cdots \mathrm{O} / \mathrm{O}-\mathrm{H} \cdots \mathrm{Cl}$ interactions. (b) Six $(1,10-\mathrm{Hphen})^{+}$cations around $\left(\mathrm{HgCl}_{4}\right)^{2-}$. Hydrogen atoms that do not interact with the anion are omitted for clarity. (c) $\mathrm{Cl} \cdots \pi$ interactions. Dashed black lines pinpoint the distance of $\mathrm{Cl}$ to the plane containing the aromatic rings. 
Table 6. Intermolecular Interactions of $(1,10-\mathrm{Hphen})_{2}\left(\mathrm{HgBr}_{4}\right)(5)^{a}$

\begin{tabular}{|c|c|c|c|c|c|}
\hline interaction & 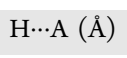 & $\mathrm{D} \cdots \mathrm{A}(\AA)$ & D-H $(\AA)$ & \multicolumn{2}{|c|}{$>\mathrm{D}-\mathrm{H} \cdots \mathrm{A}\left({ }^{\circ}\right)$} \\
\hline $\mathrm{N}(1)-\mathrm{H}(1 \mathrm{~N}) \cdots \mathrm{Br}(1)$ & 2.412 & $3.15(1)$ & 0.88 & 141.18 & \\
\hline $\mathrm{N}(3)-\mathrm{H}(3 \mathrm{~N}) \cdots \mathrm{Br}(4)$ & 2.409 & $3.12(1)$ & 0.88 & 138.19 & \\
\hline $\mathrm{C}(1)-\mathrm{H}(1) \cdots \mathrm{Br}(3)$ & 2.753 & $3.61(2)$ & 0.95 & 150.05 & \\
\hline $\mathrm{C}(1)-\mathrm{H}(1) \cdots \mathrm{Br}(1)$ & 2.935 & $3.41(1)$ & 0.95 & 112.08 & \\
\hline $\mathrm{C}(2)-\mathrm{H}(2) \cdots \mathrm{Br}(4)$ & 2.982 & $3.71(1)$ & 0.95 & 133.91 & \\
\hline $\mathrm{C}(3)-\mathrm{H}(3) \cdots \mathrm{Br}(1)$ & 2.728 & $3.64(1)$ & 0.95 & 160.67 & \\
\hline $\mathrm{C}(6)-\mathrm{H}(6) \cdots \mathrm{Br}(2)$ & 2.863 & $3.78(2)$ & 0.95 & 163.42 & \\
\hline $\mathrm{C}(13)-\mathrm{H}(13) \cdots \mathrm{Br}(4)$ & 2.841 & $3.35(2)$ & 0.95 & 114.35 & \\
\hline $\mathrm{C}(13)-\mathrm{H}(13) \cdots \mathrm{Br}(1)$ & 2.647 & $3.52(1)$ & 0.95 & 153.50 & \\
\hline $\mathrm{C}(14)-\mathrm{H}(14) \cdots \mathrm{Br}(2)$ & 2.747 & $3.57(1)$ & 0.95 & 146.05 & \\
\hline $\mathrm{C}(15)-\mathrm{H}(15) \cdots \mathrm{Br}(4)$ & 2.539 & $3.47(2)$ & 0.95 & 165.58 & \\
\hline $\mathrm{C}(18)-\mathrm{H}(18) \cdots \mathrm{Br}(3)$ & 2.826 & $3.74(2)$ & 0.95 & 163.58 & \\
\hline \multicolumn{6}{|l|}{$\pi \cdots \pi$ interactions } \\
\hline $\mathrm{Cg}(1) \cdots \mathrm{Cg}(3)$ & $3.621 \AA$ & $66.63^{\circ}$ & $\mathrm{Cg}(2) \cdots \mathrm{Cg}(2)$ & $3.613 \AA$ & $78.51^{\circ}$ \\
\hline $\mathrm{Cg}(3) \cdots \mathrm{Cg}(1)^{\prime}$ & $3.633 \AA$ & $65.28^{\circ}$ & & & \\
\hline
\end{tabular}

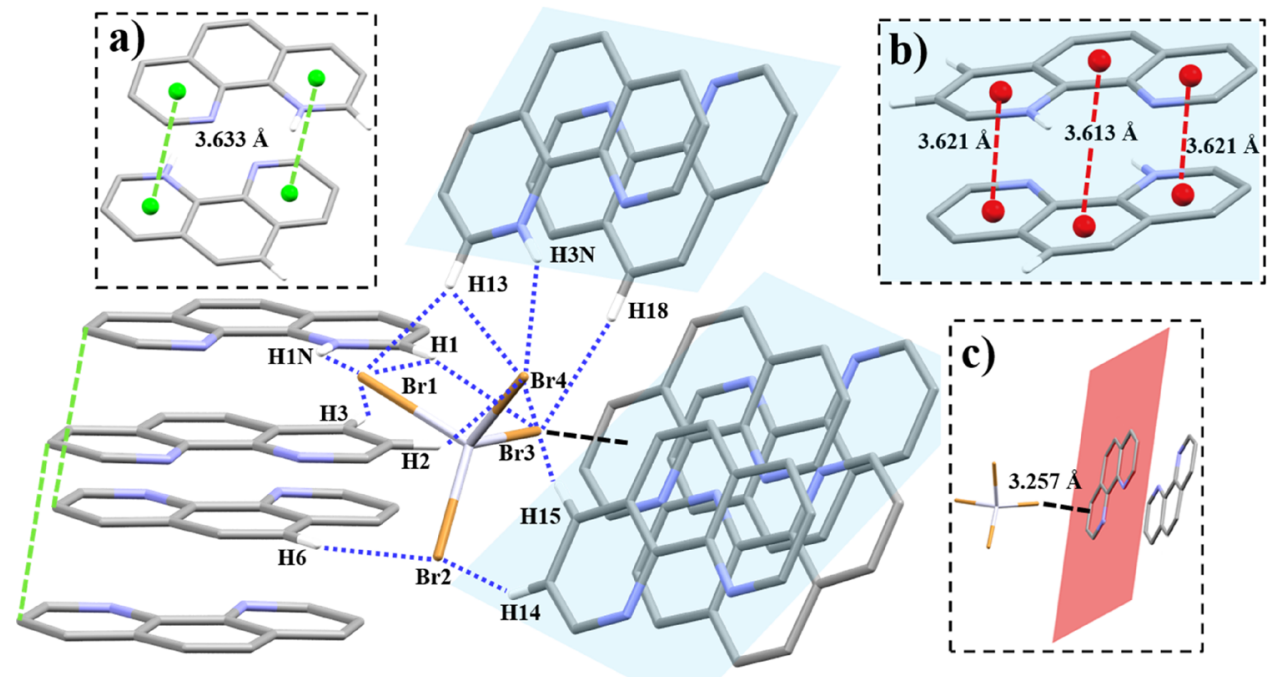

Figure 6. Intermolecular interaction of $(1,10-\mathrm{Hphen})_{2}\left(\mathrm{HgBr}_{4}\right)(5)$. Hydrogen atoms not involved in the interactions are omitted for clarity.

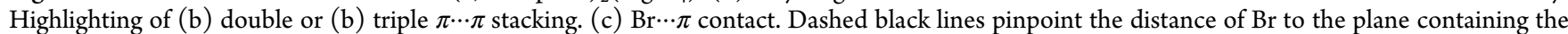
aromatic rings.

a)

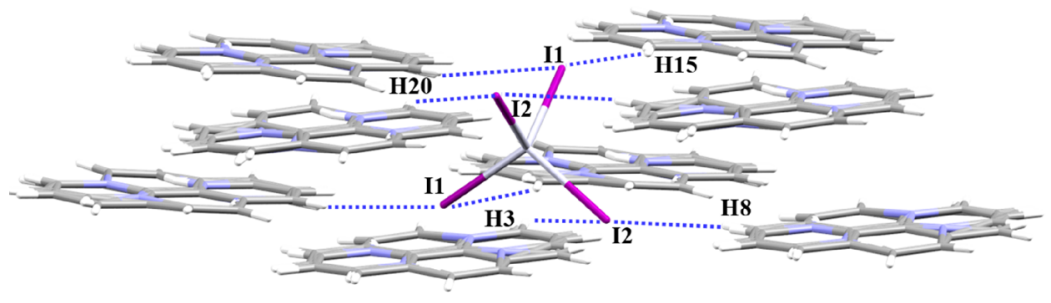

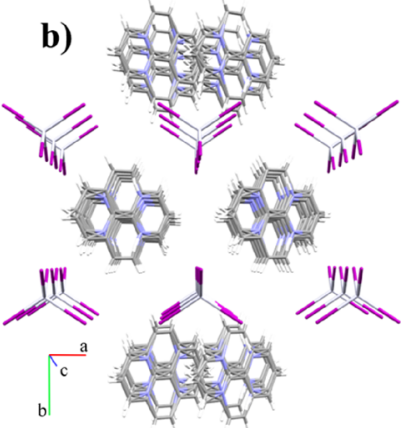

Figure 7. (a) Intermolecular interaction of $(1,10-\mathrm{Hphen})_{2}\left(\mathrm{HgI}_{4}\right)(6)$. (b) View of the piled packing of the anions or cations.

The smaller radius of $\mathrm{Cl}(1.75 \AA)$ compared to $\mathrm{Br}(1.85 \AA)$ and I (1.98 $\AA$ ), in combination with its higher electronegativity, allowed the formation of dimeric units linearly assembled through semi-coordination bonds. In the case of $\mathrm{Br}$, which is midway in size, there is a clear directional $\mathrm{Hg}$ (II) $\cdots \mathrm{Br}$ interaction, out-of-bond range but enough to maintain the linear disposition of the monomeric units. On the contrary, the bigger radius and lower electronegativity of I weaken this association and facilitate the distortion of the linear disposition. The intra-chain $\mathrm{Hg}$ (II) $\cdots \mathrm{Hg}$ (II) distance increases in the order $\mathbf{1}>\mathbf{2}>3$ being 4.3595 (4) $\AA$, 6.3546 (5) $\AA$, and 6.9656 (5) Å, respectively. 
Table 7. Intermolecular Interactions of $(1,10-$ Hphen $)_{2}\left(\mathrm{HgI}_{4}\right)(6)^{a}$

\begin{tabular}{lclcc}
\multicolumn{1}{c}{ interaction } & $\begin{array}{c}\mathrm{H} \cdots \mathrm{A} \\
(\AA)\end{array}$ & $\mathrm{D} \cdots \mathrm{A}(\AA)$ & $\begin{array}{c}\mathrm{D}-\mathrm{H} \\
(\AA)\end{array}$ & $\begin{array}{c}>\mathrm{D}-\mathrm{H} \cdots \mathrm{A} \\
\left({ }^{\circ}\right)\end{array}$ \\
$\mathrm{C}(3)-\mathrm{H}(3) \cdots \mathrm{I}(2)$ & 3.1712 & $3.913(8)$ & 0.951 & 136.25 \\
$\mathrm{C}(8)-\mathrm{H}(8) \cdots \mathrm{I}(2)$ & 3.0707 & $3.844(8)$ & 0.950 & 136.70 \\
$\mathrm{C}(15)-\mathrm{H}(15) \cdots \mathrm{I}(1)$ & 3.0829 & $3.871(10)$ & 0.950 & 141.30 \\
$\mathrm{C}(20)-\mathrm{H}(20) \cdots \mathrm{I}(1)$ & 3.1712 & $3.913(8)$ & 0.950 & 136.25 \\
$\pi \cdots \pi$ interactions & & & & \\
$\mathrm{Cg}(1) \cdots \mathrm{Cg}(2)$ & $3.750 \AA$ & & $50.08^{\circ}$ & \\
${ }^{a} \mathrm{Cg}(1): \mathrm{N} 3-\mathrm{C} 13-\mathrm{C} 14-\mathrm{C} 15-\mathrm{C} 16-\mathrm{C} 24 ;$ & $\mathrm{Cg}(2): \mathrm{C} 16-\mathrm{C} 17-$ \\
$\mathrm{C} 18-\mathrm{C} 19-\mathrm{C} 23-\mathrm{C} 24$.
\end{tabular}

Since 2,2'-bipyridine tends to be in trans conformation and is not planar, ${ }^{47}$ its diprotonation with the consequent positive charge repulsion probably emphasize it. Planarity decreased from mono- to diprotonation (rings torsion angle: 1.53 and $2.66^{\circ}(1), 34.66^{\circ}(2)$, and $\left.51.74^{\circ}(3)\right)$ and thus, $\pi \cdots \pi$ interactions are not favored in 2 and 3 . What should be noted is the nearly planar $\left(2,2^{\prime} \text {-Hbipy }\right)^{+}$. The lone electron pair of the neighboring $\mathrm{N}$ atom could stabilize the pyridinium proton and retain the planarity, favoring the assembly of $\left(2,2^{\prime}-\mathrm{Hbipy}\right)^{+}$ cations through weak $\pi \cdots \pi$ interactions.

Structures Containing (1,10-Hphen) ${ }^{+}$(4-6). In compounds 4 and 5 , the Hirshfeld surface analysis with $2 \mathrm{D}$ fingerprint plot of $\mathrm{N}-\mathrm{H} / \mathrm{C}-\mathrm{H} \cdots \mathrm{X}$ interactions (Figure 10) has similar distance values compared to that of $1-3$, the percentages of the surface being decreased (16.2 and 17.2 (4) and 22.5 and $22.7(5)$ ) because cations tend to interact between themselves by $\pi \cdots \pi$ interactions (Table 9 ).

The structural rigidity of $(1,10-\mathrm{Hphen})^{+}$cations hinders the rotation of the rings and the consequent loss of planarity, and this structural feature promotes the formation of double or triple $\pi \cdots \pi$ interactions between the cations. Likewise, $\mathrm{X} \cdots$ $\mathrm{Hg}$ (II) interactions are negligible, the percentage of the surface being 0.0 .

The intra-chain $\mathrm{Hg}(\mathrm{II}) \cdots \mathrm{Hg}$ (II) distance tendency in $4-6$ is not in line with that observed in 1-3, probably as a result of the spacing promoted by the presence of the water molecule in 4, being 8.3158 (5), 7.8160 (7), and 8.911 (1) A, respectively.

The DD maps of the cations in 4 and 5 exhibit a similar behavior of the $\mathrm{N}-\mathrm{H} / \mathrm{C}-\mathrm{H} \cdots \mathrm{X}$ interactions, suggesting the presence of halogen $\sigma$-holes but in this case, the polarization over the aromatic $\mathrm{H}$ atoms of the cations has bigger $\mathrm{CC}$ regions. The $(1,10-\mathrm{Hphen})^{+}$cations are close between them probably because they are bulkier and thus, the proximity of the positively charged $\mathrm{N}-\mathrm{H}^{+}$from neighboring cations promotes the formation of these CC regions (Figure 11). Halogen atoms are likely to interact with electron-deficient $\pi$ systems over the periphery of the rings. ${ }^{4,5}$ Figure $11 \mathrm{a}, \mathrm{c}$ illustrates the $\mathrm{Cl} \cdots \pi$ and $\mathrm{Br} \cdots \pi$ interactions, respectively. In both, the halogen atoms are directed to the periphery of the $(1,10-\mathrm{Hphen})^{+}$rings at a distance of $3.512(2) \AA(\mathrm{Cl}(3) \cdots \mathrm{C}$ (17)) and $3.383(2) \AA(\mathrm{Cl}(3) \cdots \mathrm{C}(16))$ in 4 or at $3.36(1) \AA$ $(\mathrm{Br}(3) \cdots \mathrm{N}(3))$ and $3.39(2) \AA(\mathrm{Br}(3) \cdots \mathrm{C}(13))$ in 5. This preferential orientation has a more electrostatic character, and it has been proven to promote CTs between the halogen atom and the electron-deficient $\pi$ system. ${ }^{5}$

Overall, the $(1,10-\mathrm{Hphen})^{+}$retention of planarity promoted the formation of layered crystal structures increasingly from 4 to 6 (Figure 12). Withal, the planarity of $\left(2,2^{\prime} \text {-Hbipy }\right)^{+}$in $\mathbf{1}$ resulted in an intermediate packing being the cations with similar disposition to the structures of 4-6 but without the formation of layers. Finally, the trans conformation of $\left(2,2^{\prime}\right.$ $\mathrm{H}_{2}$ bipy) ${ }^{2+}$ in 2 and 3 leads to the worst cation $\cdots$ cation
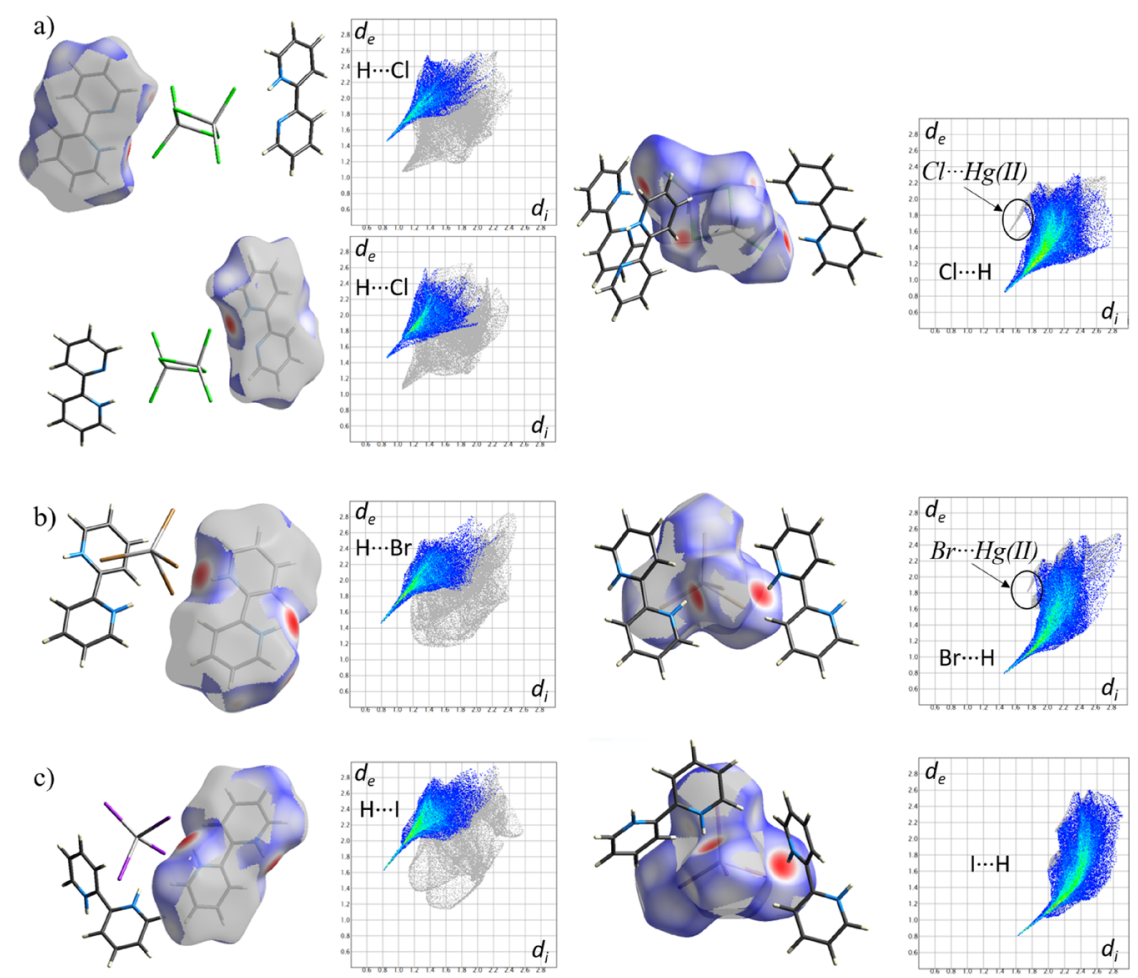

Figure 8. Hirshfeld surface representation and $2 \mathrm{D}$ fingerprint plot of the organic cations (left) and inorganic anions (right) of compounds (a) $\left(2,2^{\prime}-\mathrm{Hbipy}\right)_{2}\left(\mathrm{Hg}_{2} \mathrm{Cl}_{6}\right)(\mathbf{1})$, (b) $\left(2,2^{\prime}-\mathrm{H}_{2}\right.$ bipy $)\left(\mathrm{HgBr}_{4}\right)(2)$, and (c) $\left(2,2^{\prime}-\mathrm{H}_{2}\right.$ bipy $)\left(\mathrm{HgI}_{4}\right)$ (3). 
Table 8. Percentage (\%) of Hirshfeld Surface Implied in Each Interaction for Compounds $1-3(\mathrm{X}=\mathrm{Cl}(1), \mathrm{Br}(2)$, and I (3))

\begin{tabular}{|c|c|c|c|c|c|c|c|c|}
\hline \multicolumn{4}{|c|}{ inorganic anions } & \multicolumn{5}{|c|}{ organic cations } \\
\hline interaction & 1 & 2 & 3 & interaction & & & 2 & 3 \\
\hline $\mathrm{X} \cdots \mathrm{Hg}(\mathrm{II})$ & 3.0 & 1.5 & 0.1 & $\mathrm{~N} \cdots \mathrm{X}$ & 1.0 & 3.0 & 3.0 & 3.0 \\
\hline $\mathrm{X} \cdots \mathrm{X}$ & 2.2 & 7.9 & 4.1 & $\mathrm{H} \cdots \mathrm{X}$ & 31.5 & 28.8 & 42.6 & 50.1 \\
\hline $\mathrm{X} \cdots \mathrm{N}$ & 2.2 & 3.4 & 2.8 & $\mathrm{C} \cdots \mathrm{C}$ & 8.0 & 8.2 & 3.4 & 1.7 \\
\hline $\mathrm{X} \cdots \mathrm{C}$ & 6.0 & 8.9 & 10.3 & $C \cdots X$ & 3.7 & 3.1 & 7.0 & 9.7 \\
\hline $\mathrm{X} \cdots \mathrm{H}$ & 78.3 & 73.4 & 78.7 & & & & & \\
\hline $\mathrm{Hg} \cdots \mathrm{X}$ & 3.8 & 1.8 & 0.2 & & & & & \\
\hline
\end{tabular}
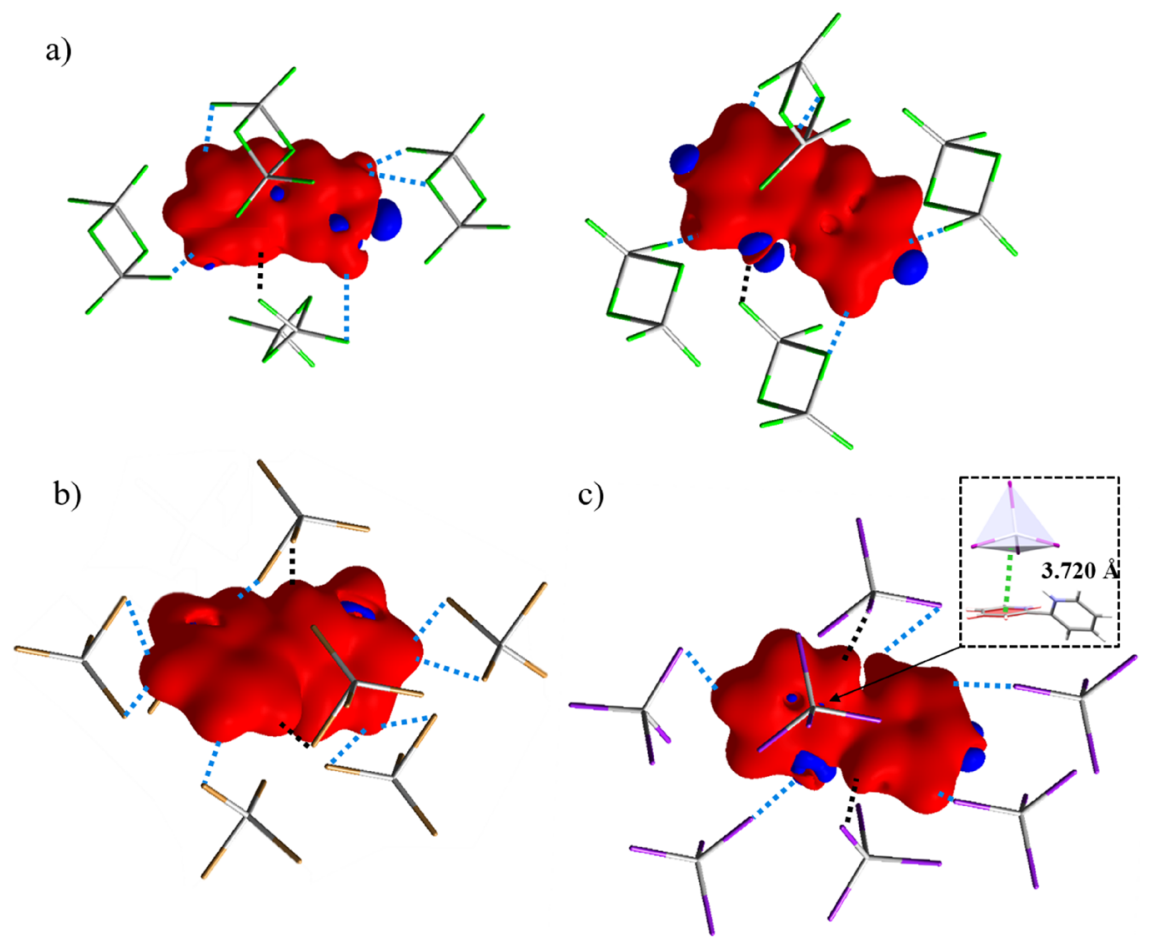

Figure 9. 3D deformation density maps of compounds (a) 1, (b) 2, and (c) 3 highlighting CD (red) and CC (blue) regions. Dashed black lines indicate $\mathrm{N}-\mathrm{H} \cdots \mathrm{X}$ contacts, while dashed blue lines highlight $\mathrm{C}-\mathrm{H} \cdots \mathrm{X}$ interactions $(\mathrm{X}=\mathrm{Cl}(\mathbf{1}), \mathrm{Br}(2)$, and $\mathrm{I}(3))$. In detail, haptic-like interaction in panel (c). The isosurfaces are drawn at $0.008 \mathrm{eau}^{-3}$.

interaction and the intersperse distribution of the anions and cations.

Electronic Structure Analysis of 1-6. With the aim of analyzing the electronic structure and the effect of halide and organic cation on the band gap of the six salts, PBE-D2 $2^{48,49}$ periodic boundary calculations using the VASP $\operatorname{code}^{50,51}$ were performed (see details in the Experimental Section). The projected density of states (pDOS) of the six compounds around the Fermi level are shown in Figure 13a-f. In this figure, we report the total DOS (black curves) and the contributions arising from $\mathrm{Hg}$ (II) centers (red curve), the halogen atoms (green curve), and the organic cations (blue curve). Noteworthily, the pDOS reports the number of electronic states at a given energy, thus defining the electronic bands of the compounds and the corresponding band gap.

For all compounds, the conducting band is mainly composed of the $\mathrm{p}$ orbitals of the organic cation, the contribution of $\mathrm{Hg}(\mathrm{II})$ and the halide atom being always small. In particular, the contribution of the organic cation to this conducting band shows less pronounced peaks for 5 and $\mathbf{6}$. This suggests a larger electronic delocalization, which could be associated with a stronger $\pi \cdots \pi$ interaction between the organic cations in these two salts. Instead, the composition of the valence band shows larger variations. Within this frame, all compounds show an important contribution of the $\mathrm{p}$ orbitals of the halogen atom, the peaks for 5 (Figure 13e) and 6 (Figure 13f) being sharper where no inorganic-inorganic interactions are identified. However, in $(1,10-\text { Hphen })^{+}$and/or chlorine-containing salts (Figure 13a,d-f), the contributions to the valence band of $\mathrm{p}$ orbitals from the organic cation are not neglectable.

This is particularly remarkable for $\mathbf{4}$ where the highest in energy occupied states are mainly composed of $(1,10-\mathrm{Hphen})^{+}$ $\mathrm{p}$ orbitals. Therefore, the most likely excitations are expected to involve charge-transfer processes for bromine and iodine salts while for chlorine species, the charge-transfer character of the main excitations is expected to be smaller, particularly for 4.

The gap between the valence and conducting band is also highly dependent on the halide anion and, in a smaller extent, by the organic cation. In this context, chlorine-containing salts (1 and 4) show the largest band gaps. Moreover, within those compounds having the same organic cation, it decreases from chlorine to iodine. These results are consistent with the color of the synthetized solids: $\mathbf{1}, \mathbf{4}$, and $\mathbf{5}$ are white; $\mathbf{2}$ is pale yellow; and $\mathbf{3}$ and $\mathbf{6}$ are yellow. It may seem that the organic cation 

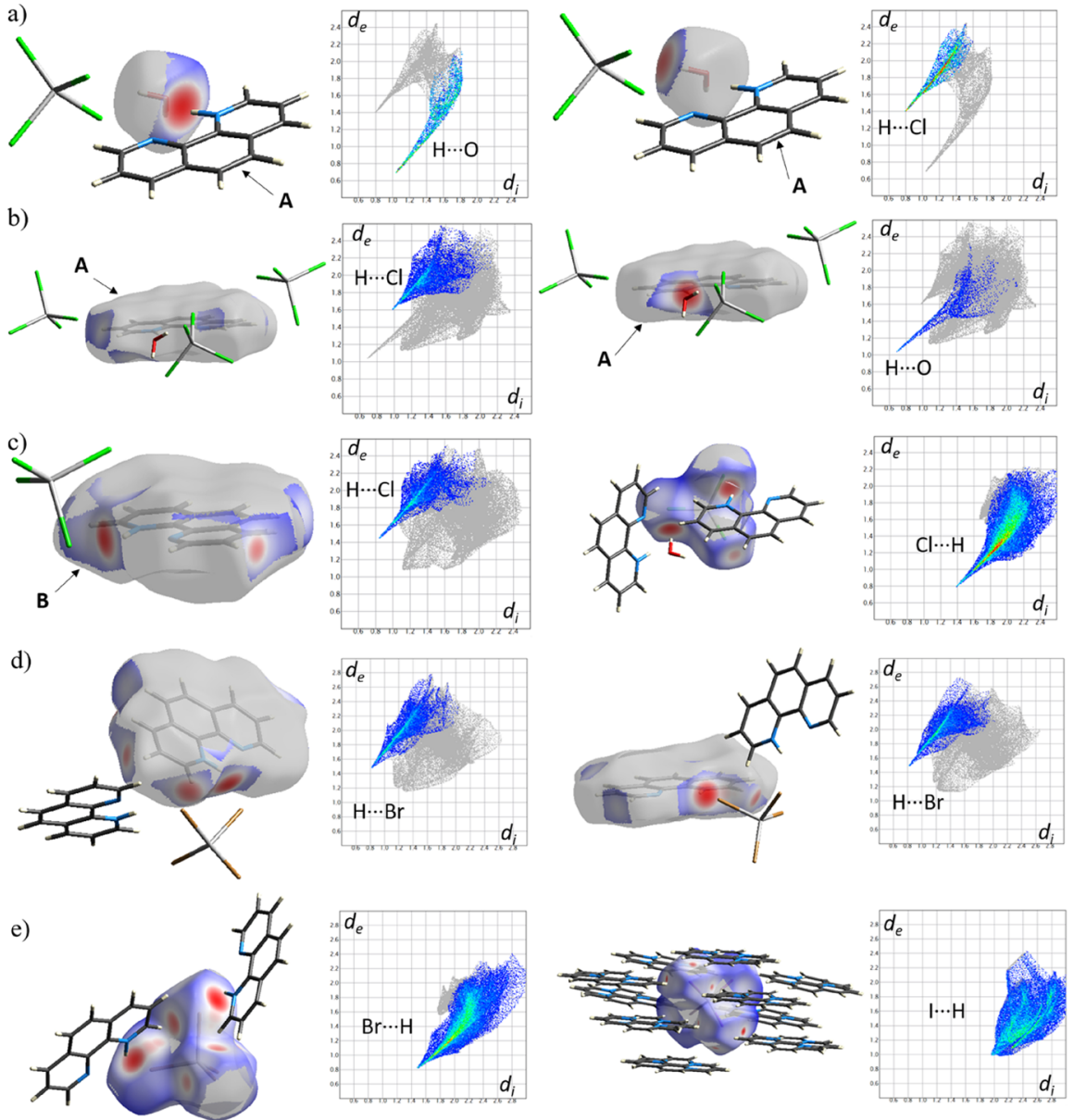

Figure 10. Hirshfeld surface and $2 \mathrm{D}$ fingerprint plot representations of (a) water molecule in 4; (b) $(1,10-\mathrm{Hphen})^{+}$associated with water in 4, appointed as $A$; (c) $(1,10-\mathrm{Hphen})^{+}$associated with $\left(\mathrm{HgCl}_{4}\right)^{2-}$ appointed as $B$ (left) and $\left(\mathrm{HgCl}_{4}\right)^{2-}$ anion in 4 (right); (d) two different (1,10Hphen $)^{+}$in 5; and (e) $\left(\mathrm{HgBr}_{4}\right)^{2-}$ (left) (5) and $\left(\mathrm{HgI}_{4}\right)^{2-}$ (right) (6) anions.

Table 9. Percentage (\%) of Hirshfeld Surface Implied in Each Interaction for Compounds 4-6 (X= Cl (4), $\mathrm{Br}(5)$, and I (6)) ${ }^{a}$

\begin{tabular}{llll}
\multicolumn{4}{c}{ inorganic anions } \\
\hline interaction & $\mathbf{4}$ & $\mathbf{5}$ & $\mathbf{6}$ \\
$\mathrm{X} \cdots \mathrm{Hg}(\mathrm{II})$ & 0.0 & 0.0 & 0.0 \\
$\mathrm{X} \cdots \mathrm{X}$ & 0.0 & 0.0 & 0.9 \\
$\mathrm{X} \cdots \mathrm{N}$ & 3.9 & 2.4 & 0.1 \\
$\mathrm{X} \cdots \mathrm{C}$ & 9.0 & 8.3 & 4.1 \\
$\mathrm{X} \cdots \mathrm{H}$ & 83.0 & 85.6 & 90.9 \\
$\mathrm{Hg} \cdots \mathrm{X}$ & 0.0 & 0.0 & 0.0
\end{tabular}

\begin{tabular}{llllrr}
\multicolumn{5}{c}{ organic cations } \\
\hline interaction & $\mathbf{4}$ & & \multicolumn{1}{c}{$\mathbf{5}$} \\
& $A$ & $\mathrm{H}_{2} \mathrm{O}$ & \multicolumn{1}{l}{ B } & & \\
$\mathrm{N} \cdots \mathrm{X}$ & 1.0 & 0.0 & 2.0 & 0.9 & 1.0 \\
$\mathrm{H} \cdots \mathrm{X}$ & 16.2 & 33.4 & 17.2 & 22.5 & 22.7 \\
$\mathrm{C} \cdots \mathrm{C}$ & 7.7 & 0.0 & 7.5 & 10.5 & 4.7 \\
$\mathrm{C} \cdots \mathrm{X}$ & 5.3 & 0.0 & 4.2 & 3.0 & 3.2 \\
$\mathrm{O} \cdots \mathrm{H}$ & 0.0 & 27.6 & 0.0 & 0.0 & 0.0
\end{tabular}

${ }^{a}$ For identification of $A$ and $B$ see Figure 1010 ca-

nature has almost no effect on the band gap per se. However, since it has a big influence on the crystal packing, it can indirectly modify the band gap. This is particularly the case of complexes $\mathbf{2}$ and $\mathbf{5}$ that only differ on the organic cation, and they present very different band gaps (Figure 13b,e). Indeed, these two complexes show very different packing and intermolecular interactions, which appears to be the origin of this large difference between their band gaps.

In summary, optical properties of these compounds are associated with charge-transfer processes from the halogen atoms to the organic cations being more pronounced for bromine- and iodine-containing compounds. The energy difference between the valence and conducting band is largely influenced by the halogen, decreasing the band gap as $\mathrm{Cl}>\mathrm{Br}$ $>$ I. In this set of compounds, the organic cation has directly little influence on the band gap of the different salts, but as clearly suggested for the bromine-containing compounds (2 and 5), it is capable of indirectly modifying the band gap through its effect on the crystal packing.

\section{CONCLUSIONS}

A series of six $\mathrm{Hg}(\mathrm{II})$ halides $(\mathrm{Cl}, \mathrm{Br}$, and $\mathrm{I})$ with aromatic conjugated $\left(2,2^{\prime}-\mathrm{Hbipy}\right)^{+},\left(2,2^{\prime}-\mathrm{H}_{2} \text { bipy }\right)^{2+}$ and $(1,10-\mathrm{Hphen})^{+}$ cations have been synthesized. The study of their crystal structures enabled the identification of the intermolecular interactions and revealed their effect on the final packing. The small size and electronegativity of chlorine promoted a shorter anion $\cdots$ anion intra-chain distance than $\mathrm{Br}$ and $\mathrm{I}$. In this regard, the bulkiness of the $(1,10-\text { Hphen })^{+}$cations does not 


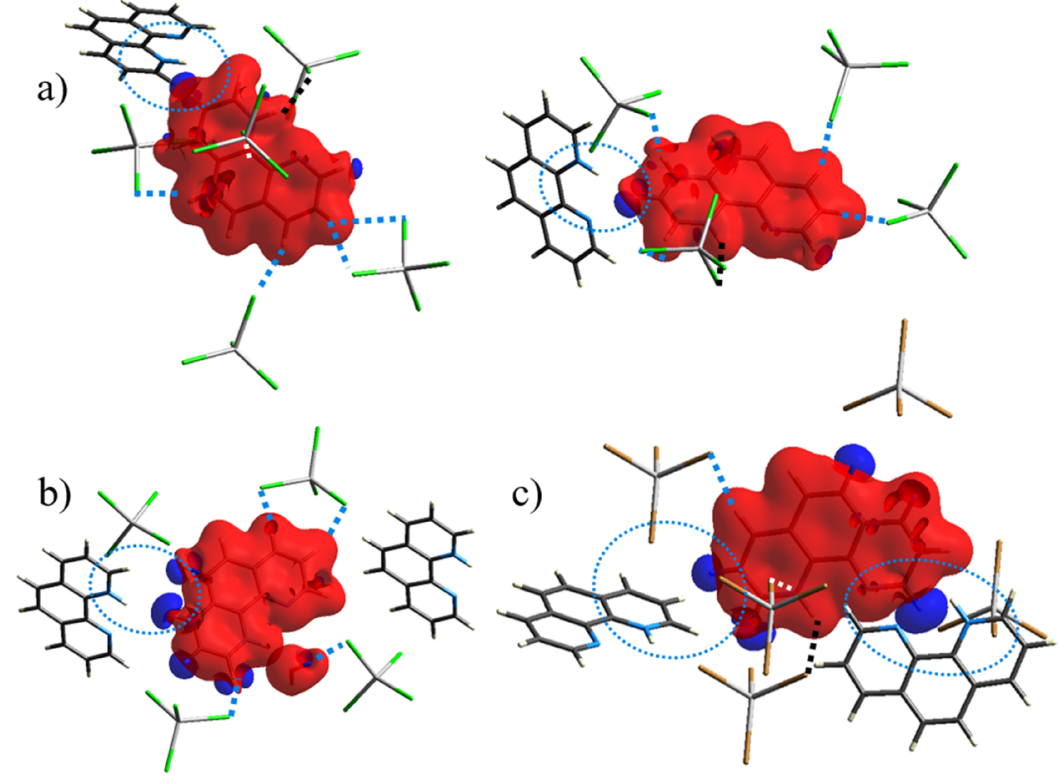

Figure 11. 3D deformation density maps highlighting $\mathrm{CD}$ (red) and $\mathrm{CC}$ (blue) regions of (a) $(1,10-\mathrm{Hphen})^{+} \ldots \mathrm{Cl}$ and $(\mathrm{b})(1,10-\mathrm{Hphen})^{+} \ldots \mathrm{H}_{2} \mathrm{O}$ associated in $\mathbf{4}$ and (c) $(1,10-\mathrm{Hphen})^{+} \cdots \mathrm{Br}$ associated in $\mathbf{5}$. Dashed black lines indicate $\mathrm{N}-\mathrm{H} \cdots \mathrm{X}$ contacts, dashed blue lines highlight $\mathrm{C}-\mathrm{H} / \mathrm{O}-$ $\mathrm{H} \cdots \mathrm{X}$ interactions, and dashed white lines identify $\mathrm{X} \cdots \pi$ interactions. Dashed blue circles point large CC regions. The isosurfaces are drawn at $0.008 \mathrm{eau}^{-3}$.

a)

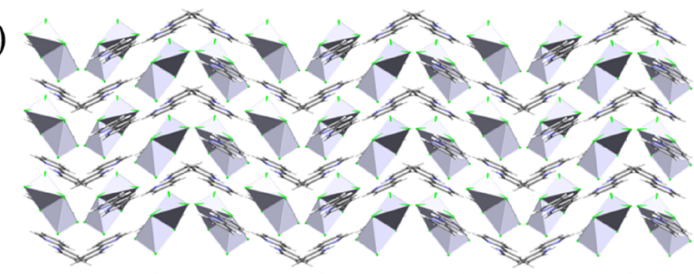

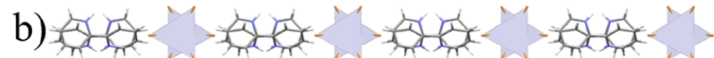

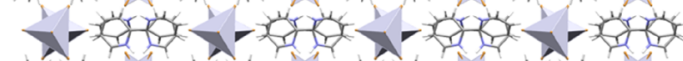

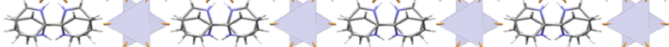
-

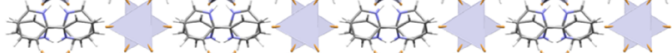

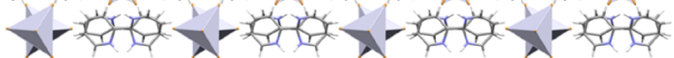

c)

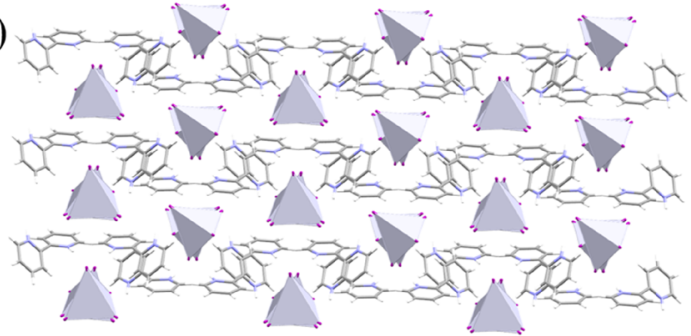

d)

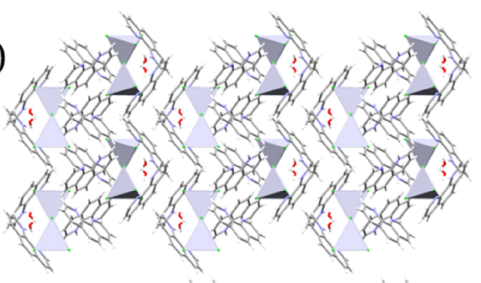

e)

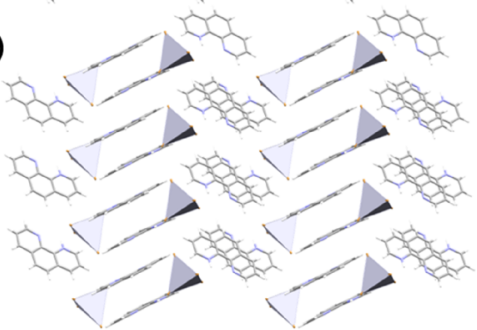

f)

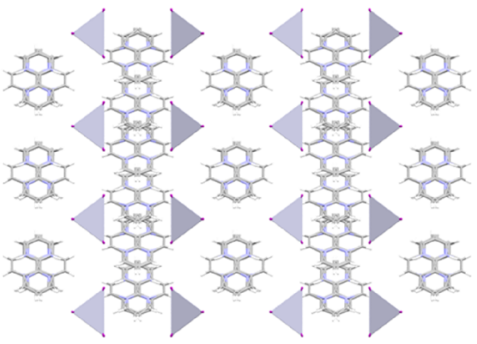

Figure 12. $c$ axis view of the crystal packing in (a-f) compounds $1-6$, respectively.

particularly increase this spacing but instead lengthens the anion $\cdots$ anion inter-chain distance located at the sides of these chains. In addition, their planarity promoted the stacking of the ring, shortening the cation $\cdots$ cation distance. The electronic structure calculations revealed the $\mathrm{p}$ orbitals of the organic cations as main contributors to the conducting band, while those of the halides defined the valence band. The electron transport in $\mathbf{1 - 6}$ is expected to involve charge-transfer processes favored in $2,3,5$, and 6 where the band gap falls within the appropriate range for their potential application as light absorbers. Despite the band gap being highly dependent on the halide and following the series $\mathrm{Cl}>\mathrm{Br}>\mathrm{I}$, the modification of the crystal packing by the cations can substantially vary it. This has been evinced in the pair of compounds 2 and 4, in which the better organic-inorganic interactions in $\mathbf{2}$ promoted a smaller band gap.

\section{EXPERIMENTAL SECTION}

Chemical Risks. Any mercury compound poses potential health risks, and appropriate safety precautions along with 


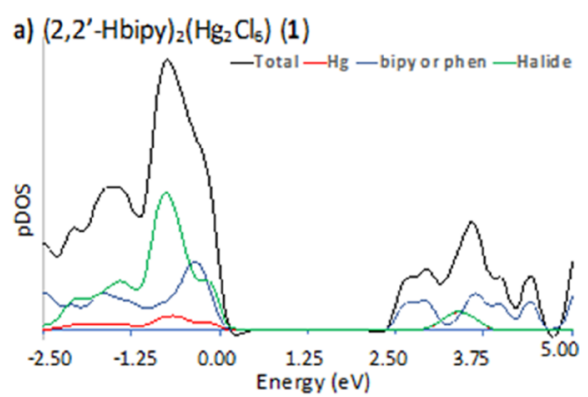

b) $\left(2,2^{\prime}-\mathrm{H}_{2}\right.$ bipy) $\left(\mathrm{HgBr}_{4}\right)(2)$

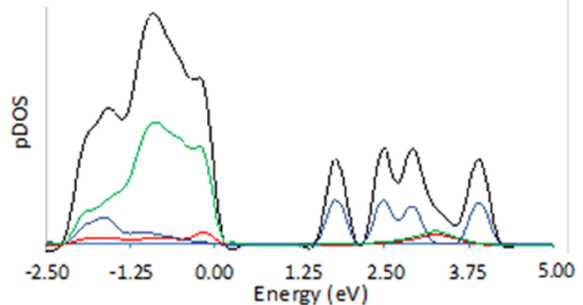

e) $(1,10-\text { Hphen })_{2}\left(\mathrm{HgBr}_{4}\right)(5)$

d) $(1,10-\mathrm{Hphen})_{2}\left(\mathrm{HgCl}_{4}\right)(\mathbf{4})$
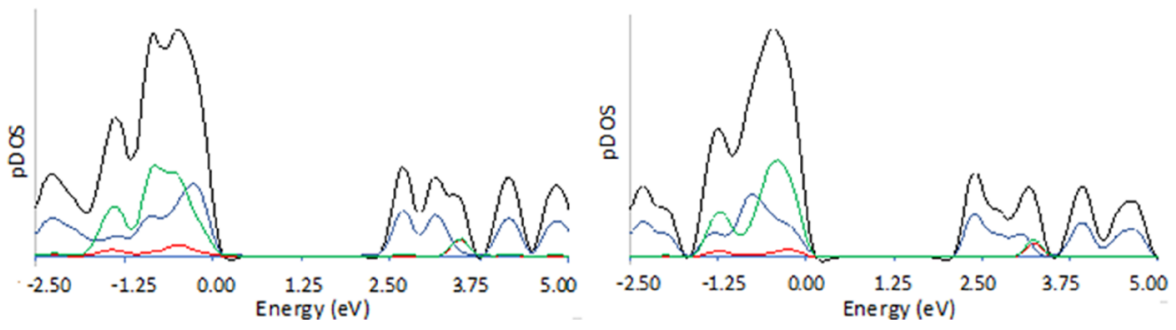

c) $\left(2,2^{\prime}-\mathrm{H}_{2}\right.$ bipy $)\left(\mathrm{Hgl}_{4}\right)(3)$

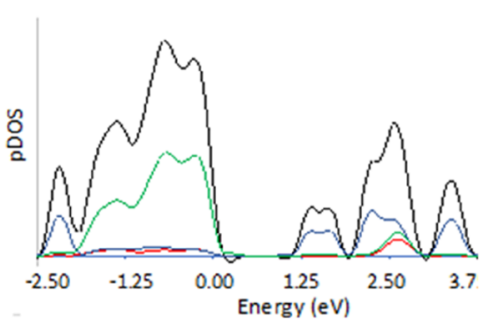

f) $(1,10-\mathrm{Hphen})_{2}\left(\mathrm{Hgl}_{4}\right)(6)$

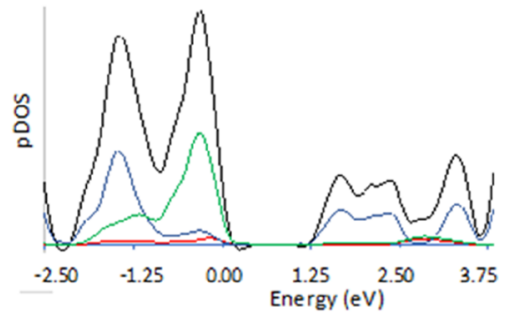

Figure 13. Projected density of states (pDOS) of the six compounds. Energies are referred to the Fermi level. The total (black curve) DOS is decomposed in those states arising from $\mathrm{Hg}$ (II) (red curve), the organic cation (blue curve), and the halogen atoms (green curve).

disposal procedures must be taken in handling the complexes reported here. $\mathrm{Hg}$ (II) halides sublime to emit highly poisonous fumes and must be handled only under appropriate conditions.

Materials and Methods. $\mathrm{Hg}(\mathrm{II})$ halides $\left(\mathrm{HgCl}_{2}, \mathrm{HgBr}_{2}\right.$, and $\mathrm{HgI}_{2}$ ), 2,2'-bipyridine (2,2'-bipy), 1,10-phenantroline monohydrate (1,10-phen), methanol $(\mathrm{MeOH})$, and dichloromethane $\left(\mathrm{CH}_{2} \mathrm{Cl}_{2}\right)$ solvents as well as hydrobromic acid $(\mathrm{HBr}$, 48 wt. \%) and hydroiodic acid (HI, 57 wt. \%) were purchased from Sigma-Aldrich. Hydrochloric acid ( $\mathrm{HCl}, 37$ wt. \%) was purchased from Scharlau. DMSO- $d_{6}$ was used for the ${ }^{1} \mathrm{H}$ NMR experiments and was purchased from Eurisotop. All of them were used without further purification. Elemental analyses (C, $\mathrm{H}$, and N) were carried out on a Thermo Scientific Flash 2000 CHNS analyzer. PXRD patterns were recorded at $298 \mathrm{~K}$ on a PANalytical X'Pert PRO MPD $\theta / \theta$ powder diffractometer of $240 \mathrm{~mm}$ radius in a configuration of a convergent beam with a focalizing mirror and a transmission geometry with flat samples sandwiched between low absorbing films from 2 to $30^{\circ}$ with a step size of $0.0263^{\circ}$ and a measuring time of 300s per step. The samples were sandwiched between films of polyester Mylar of $3.6 \mu \mathrm{m}$ of thickness. FTIR-ATR spectra were recorded on a Perkin Elmer spectrometer equipped with a universal attenuated total reflectance (ATR) accessory with a diamond window in the range $4000-500 \mathrm{~cm}^{-1}$. ${ }^{1} \mathrm{H}$ NMR spectra were recorded on an NMR-FT Bruker360 $\mathrm{MHz}$ spectrometer in DMSO- $d_{6}$ solution at room temperature (r.t.). All chemical shifts $(\delta)$ are given in ppm relative to TMS as the internal standard. Simultaneous TG/DTA determinations were carried out in a Netzsch STA 409 instrument with an aluminum oxide powder $\left(\mathrm{Al}_{2} \mathrm{O}_{3}\right)$ crucible and heating at $5{ }^{\circ} \mathrm{C} \cdot \mathrm{min}^{-1}$ from 20 to $400{ }^{\circ} \mathrm{C}$ under a nitrogen atmosphere with a flow rate of $80 \mathrm{~mL}$. $\mathrm{min}^{-1}$. $\mathrm{Al}_{2} \mathrm{O}_{3}$ (PerkinElmer 0419-0197) was used as a standard. Further experimental data and PXRD, FTIR-ATR and ${ }^{1} \mathrm{H}$ NMR spectra, and TG/DTA determinations of 1-6 are in the Supporting Information (Figures S1-S14).

Synthesis of Complexes 1-6. A methanolic solution (7 $\mathrm{mL})$ of $\mathrm{HgCl}_{2}(0.151 \mathrm{~g}, 0.557 \mathrm{mmol})$ was added dropwise to a $\mathrm{CH}_{2} \mathrm{Cl}_{2}$ solution $(14 \mathrm{~mL})$ of $2,2^{\prime}$-bipy $(0.173 \mathrm{~g}, 1.11 \mathrm{mmol})$ with $0.2 \mathrm{~mL}$ of aqueous $\mathrm{HCl}(37 \mathrm{wt} \%)$. The solution was let to evaporate slowly for 1 day until suitable crystals for singlecrystal X-ray diffraction were grown. The solution was filtered off, and the resulting crystals were washed twice with cold dichloromethane $(10 \mathrm{~mL})$ and diethyl ether $(10 \mathrm{~mL})$ and dried under vacuum.

The syntheses of 2-6 were performed by the same methodology but using the corresponding acid ( $\mathrm{HBr}$ or $\mathrm{HI}$ ) and allowing to slowly evaporate for 1 day (3 and 4), 2 days ( 2 and 5 ), or 3 days (6).

1: Yield: $0.207 \mathrm{~g}(40 \%)$. Elem. anal. calc. for $\mathrm{C}_{20} \mathrm{H}_{18} \mathrm{Hg}_{2} \mathrm{~N}_{4} \mathrm{Cl}_{6}$ (928.28 g/mol): C, 25.88; H, 1.95; N, 6.04. Found: C, 25.63; H, 1.84; N, 6.04. FTIR-ATR (wavenumber, $\left.\mathrm{cm}^{-1}\right)$ : $3236(\mathrm{w}), 3150(\mathrm{w}), 3031(\mathrm{~m})$ $\left[\nu_{\mathrm{ar}}(\mathrm{C}-\mathrm{H})\right], 2932-2322(\mathrm{~m})[\nu(\mathrm{N}-\mathrm{H})], 1600(\mathrm{~s})[\nu(\mathrm{C}=$ $\mathrm{C} / \mathrm{C}=\mathrm{N})], 1524(\mathrm{~s})[\nu(\mathrm{C}=\mathrm{C} / \mathrm{C}=\mathrm{N})], 1447(\mathrm{~m})[\nu(\mathrm{C}=\mathrm{C} /$ $\mathrm{C}=\mathrm{N})], 1387(\mathrm{~s})[\delta(\mathrm{C}=\mathrm{C} / \mathrm{C}=\mathrm{N})], 1285(\mathrm{~s}), 1242(\mathrm{~m})$, $1165(\mathrm{w})\left[\delta_{\text {ip }}(\mathrm{C}-\mathrm{H})\right], 999(\mathrm{w}), 930(\mathrm{w})[\gamma(\mathrm{N}-\mathrm{H})], 802(\mathrm{w})$, $760(\mathrm{~s})\left[\delta_{\text {oop }}(\mathrm{C}-\mathrm{H})\right], 623(\mathrm{w}), 541(\mathrm{w}) .{ }^{1} \mathrm{H}$ NMR $(360 \mathrm{MHz}$ DMSO- $\left.d_{6} ; 298 \mathrm{~K}, \mathrm{TMS}\right): \delta=4.80[\mathrm{br}, \mathrm{N}-\mathrm{H}], 7.87[2 \mathrm{H}, \mathrm{m}$, meta- $H], 8.41[2 \mathrm{H}, \mathrm{m}$, para- $\mathrm{H}], 8.66\left[2 \mathrm{H}, \mathrm{t},{ }^{3} \mathrm{~J}=7.3 \mathrm{~Hz}, \mathrm{C}-\right.$ $\mathrm{C}=\mathrm{C}-\mathrm{H}], 8.88\left[2 \mathrm{H}, \mathrm{d},{ }^{3} \mathrm{~J}=4.2 \mathrm{~Hz}\right.$, ortho- $\left.\mathrm{H}\right]$.

2: Yield: $0.209 \mathrm{~g}(74 \%)$. Elem. anal. calc. for $\mathrm{C}_{10} \mathrm{H}_{10} \mathrm{HgN}_{2} \mathrm{Br}_{4}$ (678.41 g/mol): C, 17.70; H, 1.49; N, 4.13. Found: C, 17.62; $\mathrm{H}, 1.42 ; \mathrm{N}, 4.08$. FTIR-ATR (wavenumber, $\mathrm{cm}^{-1}$ ): 3373 (br) $[\nu(\mathrm{N}-\mathrm{H})], 3232(\mathrm{w}), 3138-3023(\mathrm{~m})\left[\nu_{\mathrm{ar}}(\mathrm{C}-\mathrm{H})\right], 2983-$ $2631(\mathrm{~m})[\nu(\mathrm{N}-\mathrm{H})], 1599(\mathrm{~s})[\nu(\mathrm{C}=\mathrm{C} / \mathrm{C}=\mathrm{N})], 1563(\mathrm{w})$, $1542(\mathrm{w}), 1523(\mathrm{~s})[\nu(\mathrm{C}=\mathrm{C} / \mathrm{C}=\mathrm{N})], 1473(\mathrm{w}), 1443(\mathrm{~m})$ $[\nu(\mathrm{C}=\mathrm{C} / \mathrm{C}=\mathrm{N})], 1411(\mathrm{w}), 1385(\mathrm{~m})[\delta(\mathrm{C}=\mathrm{C} / \mathrm{C}=\mathrm{N})]$, $1281(\mathrm{~m}), 1240(\mathrm{~m}), 1167(\mathrm{w})\left[\delta_{\text {ip }}(\mathrm{C}-\mathrm{H})\right], 1088(\mathrm{w}), 1073$ $(\mathrm{w}), 1040(\mathrm{w}), 1014(\mathrm{w}), 997(\mathrm{w}), 940(\mathrm{w}), 920(\mathrm{~m})[\gamma(\mathrm{N}-$ $\mathrm{H})], 871(\mathrm{w}), 860(\mathrm{w}), 791(\mathrm{w}), 753(\mathrm{~s})\left[\delta_{\text {oop }}(\mathrm{C}-\mathrm{H})\right], 735$ (s) $\left[\delta_{\text {oop }}(\mathrm{C}-\mathrm{H})\right], 714(\mathrm{~m}), 623(\mathrm{~m}), 538(\mathrm{~m}) .{ }^{1} \mathrm{H}$ NMR $(360$ MHz; DMSO- $\left.d_{6} ; 298 \mathrm{~K}, \mathrm{TMS}\right): \delta=5.32[\mathrm{br}, \mathrm{N}-\mathrm{H}], 7.88$ $\left[2 \mathrm{H}, \mathrm{dd},{ }^{3} \mathrm{~J}=7.9 \mathrm{~Hz},{ }^{3} \mathrm{~J}=5.0 \mathrm{~Hz}\right.$, meta- $\left.\mathrm{H}\right], 8.42\left[2 \mathrm{H}, \mathrm{td},{ }^{3} \mathrm{~J}=\right.$ $7.9 \mathrm{~Hz},{ }^{4} J=2.0 \mathrm{~Hz}$, para $\left.-\mathrm{H}\right], 8.66\left[2 \mathrm{H}, \mathrm{d},{ }^{3} \mathrm{~J}=8.1 \mathrm{~Hz}, \mathrm{C}-\mathrm{C}=\right.$ $\mathrm{C}-\mathrm{H}], 8.89\left[2 \mathrm{H}, \mathrm{dd},{ }^{3} \mathrm{~J}=5.1 \mathrm{~Hz},{ }^{4} \mathrm{~J}=1.7 \mathrm{~Hz}\right.$, ortho-H].

3: Yield: $0.152 \mathrm{~g}$ (53\%). Elem. anal. calc. for $\mathrm{C}_{10} \mathrm{H}_{10} \mathrm{HgN}_{2} \mathrm{I}_{4}$ (866.41 g/mol): C, 13.86; H, 1.16; N, 3.23. Found: C, 13.67; $\mathrm{H}, 1.05 ; \mathrm{N}, 3.11$. FTIR-ATR (wavenumber, $\mathrm{cm}^{-1}$ ): 3209 (br) 
$[\nu(\mathrm{N}-\mathrm{H})] /[\nu(\mathrm{O}-\mathrm{H})], 3091-3050(\mathrm{~m})\left[\nu_{\mathrm{ar}}(\mathrm{C}-\mathrm{H})\right], 2945$ (w), $2882(\mathrm{w}), 1627(\mathrm{w}), 1617(\mathrm{w}), 1582(\mathrm{~s})[\nu(\mathrm{C}=\mathrm{C} / \mathrm{C}=$ $\mathrm{N})], 1569(\mathrm{w}), 1525(\mathrm{~s})[\nu(\mathrm{C}=\mathrm{C} / \mathrm{C}=\mathrm{N})], 1470(\mathrm{w}), 1457$ (m) $[\nu(\mathrm{C}=\mathrm{C} / \mathrm{C}=\mathrm{N})], 1428(\mathrm{~s})[\delta(\mathrm{C}=\mathrm{C} / \mathrm{C}=\mathrm{N})], 1411$ $(\mathrm{w}), 1354(\mathrm{w}), 1326(\mathrm{~m}), 1311(\mathrm{w}), 1277(\mathrm{w}), 1247(\mathrm{w})$, $1215(\mathrm{~m}), 1178(\mathrm{~m})\left[\delta_{\text {ip }}(\mathrm{C}-\mathrm{H})\right], 1150(\mathrm{w}), 1110(\mathrm{w}), 1089$ (m), $1066(\mathrm{w}), 1037(\mathrm{w}), 1005(\mathrm{w}), 994(\mathrm{w}), 977(\mathrm{w}), 927$ $(\mathrm{m}), 917(\mathrm{~m})[\gamma(\mathrm{N}-\mathrm{H})], 861(\mathrm{w}), 809(\mathrm{w}), 754(\mathrm{~s})\left[\delta_{\text {oop }}(\mathrm{C}-\right.$ $\mathrm{H})], 737(\mathrm{~m})\left[\delta_{\text {oop }}(\mathrm{C}-\mathrm{H})\right], 720(\mathrm{~s})\left[\delta_{\text {oop }}(\mathrm{C}-\mathrm{H})\right], 644(\mathrm{w})$, $633(\mathrm{w}), 611(\mathrm{w}), 541(\mathrm{w}) .{ }^{1} \mathrm{H}$ NMR $\left(360 \mathrm{MHz}\right.$; DMSO- $d_{6}$; $298 \mathrm{~K}, \mathrm{TMS}): \delta=4.73[\mathrm{br}, \mathrm{N}-\mathrm{H}], 7.81\left[2 \mathrm{H}, \mathrm{d},{ }^{3} J=6.3 \mathrm{~Hz}\right.$, meta- $H], 8.34\left[2 \mathrm{H}, \mathrm{d},{ }^{3} \mathrm{~J}=7.9 \mathrm{~Hz}\right.$, para- $\left.\mathrm{H}\right], 8.61\left[2 \mathrm{H}, \mathrm{d},{ }^{3} \mathrm{~J}=\right.$ $8.3 \mathrm{~Hz}, \mathrm{C}-\mathrm{C}=\mathrm{C}-\mathrm{H}], 8.85\left[2 \mathrm{H}, \mathrm{d},{ }^{3} \mathrm{~J}=4.7 \mathrm{~Hz}\right.$, ortho- $\left.\mathrm{H}\right]$.

4: Yield: $0.127 \mathrm{~g}(32 \%)$. Elem. anal. calc. for $\mathrm{C}_{24} \mathrm{H}_{20} \mathrm{HgN}_{4} \mathrm{Cl}_{4} \mathrm{O}$ (722.83 g/mol): C, 39.88; H, 2.79; N, 7.75. Found: $\mathrm{C}, 39.77 ; \mathrm{H}, 2.71 ; \mathrm{N}, 7.64$. FTIR-ATR (wavenumber, $\left.\mathrm{cm}^{-1}\right)$ : 3178-2643 (br) $[\nu(\mathrm{O}-\mathrm{H} / \mathrm{N}-\mathrm{H})]$, 3090-3022 (m) $\left[\nu_{\text {ar }}(\mathrm{C}-\mathrm{H})\right], 2994(\mathrm{w}), 2948(\mathrm{w}), 1633$ $(\mathrm{w}), 1613(\mathrm{~m}), 1595(\mathrm{~m})[\nu(\mathrm{C}=\mathrm{C} / \mathrm{C}=\mathrm{N})], 1537$ (s) $[\nu(\mathrm{C}=\mathrm{C} / \mathrm{C}=\mathrm{N})], 1495(\mathrm{w}), 1464(\mathrm{~m})[\nu(\mathrm{C}=\mathrm{C} / \mathrm{C}=\mathrm{N})]$, $1452(\mathrm{~m})[\nu(\mathrm{C}=\mathrm{C} / \mathrm{C}=\mathrm{N})], 1415(\mathrm{~m})[\delta(\mathrm{C}=\mathrm{C} / \mathrm{C}=\mathrm{N})]$, $1365(\mathrm{w}), 1338(\mathrm{w}), 1315(\mathrm{w}), 1279(\mathrm{~m}), 1234(\mathrm{~m}), 1185$ $(\mathrm{m})\left[\delta_{\text {ip }}(\mathrm{C}-\mathrm{H})\right], 1152(\mathrm{w}), 1139(\mathrm{w}), 1098(\mathrm{w}), 1071(\mathrm{w})$, $1043(\mathrm{w}), 1034(\mathrm{w}), 1007(\mathrm{w}), 987(\mathrm{w}), 916(\mathrm{w})[\gamma(\mathrm{N}-\mathrm{H})]$, $883(\mathrm{w}), 844(\mathrm{~s})\left[\delta_{\text {oop }}(\mathrm{C}-\mathrm{H})\right], 819(\mathrm{~m})\left[\delta_{\text {oop }}(\mathrm{C}-\mathrm{H})\right], 802$ (sh.) $\left[\delta_{\text {oop }}(\mathrm{C}-\mathrm{H})\right], 771(\mathrm{~s})\left[\delta_{\text {oop }}(\mathrm{C}-\mathrm{H})\right], 714(\mathrm{~s})\left[\delta_{\text {oop }}(\mathrm{C}-\right.$ $\mathrm{H})$ ], $678(\mathrm{w}), 621(\mathrm{~m}), 597(\mathrm{w}), 552(\mathrm{w}), 538(\mathrm{w}), 502(\mathrm{w})$. ${ }^{1} \mathrm{H}$ NMR (360 MHz; DMSO- $d_{6}$; $\left.298 \mathrm{~K}, \mathrm{TMS}\right): \delta=4.10$ [br, $\mathrm{N}-\mathrm{H}], 8.20\left[4 \mathrm{H}, \mathrm{dd},{ }^{3} \mathrm{~J}=8.2 \mathrm{~Hz},{ }^{3} \mathrm{~J}=4.9 \mathrm{~Hz}\right.$, meta- $H$ ] 8.34 $[4 \mathrm{H}$, s, phenyl- $H], 9.05\left[4 \mathrm{H}, \mathrm{dd},{ }^{3} J=8.2 \mathrm{~Hz},{ }^{4} J=1.6 \mathrm{~Hz}\right.$, para$H], 9.29\left[4 \mathrm{H}, \mathrm{dd},{ }^{3} \mathrm{~J}=4.9 \mathrm{~Hz},{ }^{4} \mathrm{~J}=1.5 \mathrm{~Hz}\right.$, ortho- $H$ ].

5: Yield: $0.271 \mathrm{~g}$ (74\%). Elem. anal. calc. for $\mathrm{C}_{24} \mathrm{H}_{18} \mathrm{HgN}_{4} \mathrm{Br}_{4}$ (882.65 g/mol): C, 32.66; H, 2.06; N, 6.35. Found: C, 32.48; $\mathrm{H}, 1.94 ; \mathrm{N}, 6.13$. FTIR-ATR (wavenumber, $\mathrm{cm}^{-1}$ ): 3193$3172(\mathrm{~m})[\nu(\mathrm{N}-\mathrm{H})], 3099-3040(\mathrm{w})\left[\nu_{\mathrm{ar}}(\mathrm{C}-\mathrm{H})\right], 1635(\mathrm{w})$, $1613(\mathrm{~m}), 1597(\mathrm{~m})[\nu(\mathrm{C}=\mathrm{C} / \mathrm{C}=\mathrm{N})], 1542(\mathrm{~s})[\nu(\mathrm{C}=\mathrm{C} /$ $\mathrm{C}=\mathrm{N})], 1494(\mathrm{~m}), 1464(\mathrm{~s})[\nu(\mathrm{C}=\mathrm{C} / \mathrm{C}=\mathrm{N})], 1451(\mathrm{~m})$, $1417(\mathrm{~m})[\delta(\mathrm{C}=\mathrm{C} / \mathrm{C}=\mathrm{N})], 1370(\mathrm{~m})[\delta(\mathrm{C}=\mathrm{C} / \mathrm{C}=\mathrm{N})]$, $1336(\mathrm{~m}), 1314(\mathrm{~m}), 1285(\mathrm{~m}), 1242(\mathrm{~m}), 1225(\mathrm{~m}), 1182$ $(\mathrm{w})\left[\delta_{\text {ip }}(\mathrm{C}-\mathrm{H})\right], 1148(\mathrm{w}), 1097(\mathrm{w}), 1071(\mathrm{w}), 1032(\mathrm{w})$, $960(\mathrm{w})[\gamma(\mathrm{N}-\mathrm{H})], 883(\mathrm{w}), 866(\mathrm{w}), 840(\mathrm{~s})\left[\delta_{\text {oop }}(\mathrm{C}-\mathrm{H})\right]$, $807(\mathrm{~s})\left[\delta_{\text {oop }}(\mathrm{C}-\mathrm{H})\right], 794(\mathrm{~m})\left[\delta_{\text {oop }}(\mathrm{C}-\mathrm{H})\right], 755(\mathrm{~s})$ $\left[\delta_{\text {oop }}(\mathrm{C}-\mathrm{H})\right], 714(\mathrm{~s})\left[\delta_{\text {oop }}(\mathrm{C}-\mathrm{H})\right], 615(\mathrm{~m}), 529(\mathrm{~m}) .{ }^{1} \mathrm{H}$ NMR (360 MHz; DMSO-d $\left.d_{6} 298 \mathrm{~K}, \mathrm{TMS}\right): \delta=4.24$ [br, N$H], 8.22\left[4 \mathrm{H}, \mathrm{dd},{ }^{3} J=8.2 \mathrm{~Hz},{ }^{3} J=4.9 \mathrm{~Hz}\right.$, meta- $\left.\mathrm{H}\right], 8.36[4 \mathrm{H}$, s, phenyl-H], $9.07\left[4 \mathrm{H}, \mathrm{dd},{ }^{3} \mathrm{~J}=8.2 \mathrm{~Hz},{ }^{4} \mathrm{~J}=1.2 \mathrm{~Hz}\right.$, para- $\left.\mathrm{H}\right]$, $9.31\left[4 \mathrm{H}, \mathrm{dd},{ }^{3} \mathrm{~J}=4.8 \mathrm{~Hz},{ }^{4} \mathrm{~J}=1.2 \mathrm{~Hz}\right.$, ortho- $\left.\mathrm{H}\right]$.

6: Yield: $0.255 \mathrm{~g}$ (72\%). Elem. anal. calc. for $\mathrm{C}_{24} \mathrm{H}_{18} \mathrm{HgN}_{4} \mathrm{I}_{4}$ (1039.74 g/mol): C, 26.87; H, 1.69; N, 5.23. Found: C, 26.65; $\mathrm{H}, 1.52$; N, 5.04. FTIR-ATR (wavenumber, $\mathrm{cm}^{-1}$ ): 3448 (br) $[\nu(\mathrm{N}-\mathrm{H})], 3094-3052(\mathrm{w})\left[\nu_{\mathrm{ar}}(\mathrm{C}-\mathrm{H})\right], 2980(\mathrm{w}), 2942(\mathrm{w})$, $2869(\mathrm{w}), 2784(\mathrm{w}), 2738(\mathrm{w}), 2660(\mathrm{w}), 1634(\mathrm{w}), 1614$ $(\mathrm{m}), 1593(\mathrm{~s})[\nu(\mathrm{C}=\mathrm{C} / \mathrm{C}=\mathrm{N})], 1541(\mathrm{~s})[\nu(\mathrm{C}=\mathrm{C} / \mathrm{C}=$ $\mathrm{N})], 1493(\mathrm{~m})[\nu(\mathrm{C}=\mathrm{C} / \mathrm{C}=\mathrm{N})], 1467(\mathrm{~m}), 1447(\mathrm{~m}), 1414$ $(\mathrm{m})[\delta(\mathrm{C}=\mathrm{C} / \mathrm{C}=\mathrm{N})], 1378(\mathrm{~s})[\delta(\mathrm{C}=\mathrm{C} / \mathrm{C}=\mathrm{N})], 1335$ $(\mathrm{m}), 1314(\mathrm{~m}), 1287(\mathrm{~m}), 1240(\mathrm{~m}), 1221(\mathrm{w}), 1189(\mathrm{w})$ $\left[\delta_{\text {ip }}(\mathrm{C}-\mathrm{H})\right], 1147(\mathrm{w}), 1136(\mathrm{w}), 1098(\mathrm{w}), 1072(\mathrm{w}), 1029$ $(\mathrm{w}), 993(\mathrm{w}), 964(\mathrm{w})[\gamma(\mathrm{N}-\mathrm{H})], 934(\mathrm{w})[\gamma(\mathrm{N}-\mathrm{H})], 883$ $(\mathrm{w}), 840(\mathrm{~s})\left[\delta_{\text {oop }}(\mathrm{C}-\mathrm{H})\right], 823(\mathrm{~m})\left[\delta_{\text {oop }}(\mathrm{C}-\mathrm{H})\right], 807(\mathrm{sh}$. $\left[\delta_{\text {oop }}(\mathrm{C}-\mathrm{H})\right], 767(\mathrm{~m})\left[\delta_{\text {oop }}(\mathrm{C}-\mathrm{H})\right], 714(\mathrm{~s})\left[\delta_{\text {oop }}(\mathrm{C}-\mathrm{H})\right]$, $618(\mathrm{~m}), 599(\mathrm{w}), 541(\mathrm{~m}), 518(\mathrm{~m}) .{ }^{1} \mathrm{H}$ NMR (360 MHz; DMSO- $\left.d_{6} ; 298 \mathrm{~K}\right): \delta=4.39\left[\mathrm{br}, \mathrm{N}-\mathrm{H}\right.$ ] $8.23\left[4 \mathrm{H}, \mathrm{dd},{ }^{3} J=8.7\right.$
$\mathrm{Hz},{ }^{3} \mathrm{~J}=4.7 \mathrm{~Hz}$, meta- $H$ ], $8.36[4 \mathrm{H}, \mathrm{s}$, phenyl- $\mathrm{H}$ ], 9.07 [4H, d, ${ }^{3} J=8.3 \mathrm{~Hz}$, para- $\left.H\right], 9.30\left[4 \mathrm{H}, \mathrm{d},{ }^{3} J=5.1 \mathrm{~Hz}\right.$, ortho- $\left.H\right]$.

X-Ray Crystallographic Data and Electronic Calculations. Colorless $(1,4$, and 5), yellow (3), and red (6) prismlike or colorless plate-like (2) specimens were used for the Xray crystallographic analysis. For all compounds, the frames were integrated with the Bruker SAINT software package using a narrow-frame algorithm (Tables 10 and 11).

The electronic structure of $\mathbf{1 - 6}$ has been analyzed by performing periodic DFT calculations using the VASP code $^{50,51}$ All calculations were done at the PBE level of theory. ${ }^{48}$ van der Waals interactions were included through Grimme's D2 empirical correction. ${ }^{49}$ The use of D2 instead of D3 correction was based on previous results that showed that

Table 10. Crystal Structure Refinement Data for Compounds 1-3

\begin{tabular}{|c|c|c|c|}
\hline parameters & 1 & 2 & 3 \\
\hline $\begin{array}{r}\text { empirical } \\
\text { formula }\end{array}$ & $\mathrm{C}_{20} \mathrm{H}_{18} \mathrm{Cl}_{6} \mathrm{Hg}_{2} \mathrm{~N}_{4}$ & $\mathrm{C}_{10} \mathrm{H}_{10} \mathrm{Br}_{4} \mathrm{HgN}_{2}$ & $\mathrm{C}_{10} \mathrm{H}_{10} \mathrm{I}_{4} \mathrm{HgN}_{2}$ \\
\hline formula weigh & 928.26 & 678.43 & 866.39 \\
\hline$T(\mathrm{~K})$ & $100(2)$ & $100(2)$ & $100(2)$ \\
\hline wavelength ( & 0.71073 & 0.71073 & 0.71073 \\
\hline $\begin{array}{l}\text { system, space } \\
\text { group }\end{array}$ & monoclinic, $P 2_{1} / c$ & monoclinic, $P 2_{1} / c$ & $\begin{array}{l}\text { monoclinic, } \\
P 2_{1} / c\end{array}$ \\
\hline \multicolumn{4}{|l|}{$\begin{array}{l}\text { unit cell } \\
\text { dimensions }\end{array}$} \\
\hline$a(\AA)$ & $7.4413(3)$ & $8.4640(6)$ & $7.8704(4)$ \\
\hline$b(\AA)$ & $21.6102(12)$ & $14.0128(10)$ & $15.6908(7)$ \\
\hline$c(\AA)$ & $15.4817(8)$ & $12.6748(8)$ & $13.8093(7)$ \\
\hline$\beta\left(^{\circ}\right)$ & $94.962(2)$ & $99.102(2)$ & $90.282(2)$ \\
\hline$V\left(\AA^{3}\right)$ & $2480.3(2)$ & $1484.36(18)$ & $1705.33(14)$ \\
\hline$Z$ & 4 & 4 & 4 \\
\hline$D_{\text {calc }}\left(\mathrm{g} \mathrm{cm}^{3}\right)$ & 2.486 & 3.036 & 3.375 \\
\hline$\mu\left(\mathrm{mm}^{-1}\right)$ & 13.029 & 21.116 & 16.250 \\
\hline$F(000)$ & 1712 & 1216 & 1504 \\
\hline $\begin{array}{l}\text { crystal size } \\
\left(\mathrm{mm}^{3}\right)\end{array}$ & $\begin{array}{l}0.213 \times 0.089 \times \\
0.030\end{array}$ & $\begin{array}{l}0.330 \times 0.233 \times \\
0.088\end{array}$ & $\begin{array}{l}0.075 \times 0.065 \times \\
0.041\end{array}$ \\
\hline \multirow[t]{3}{*}{$h k l$ ranges } & $-10 \leq h \leq 10$ & $-10 \leq h \leq 10$ & $-11 \leq h \leq 9$ \\
\hline & $0 \leq k \leq 30$ & $0 \leq k \leq 17$ & $-22 \leq k \leq 22$ \\
\hline & $0 \leq l \leq 22$ & $0 \leq l \leq 15$ & $-18 \leq l \leq 19$ \\
\hline $2 \theta$ range $\left(^{\circ}\right)$ & $2.748-30.532$ & $2.182-26.426$ & $2.895-30.547$ \\
\hline $\begin{array}{l}\text { reflections } \\
\quad \text { collected/ } \\
\text { unique } /\left[R_{\text {int }}\right]\end{array}$ & $\begin{array}{l}7586 / 7586 /\left[R_{\text {int }}\right] \\
\quad=0.0502\end{array}$ & $\begin{array}{l}3019 / 3019 /\left[R_{\mathrm{int}}\right] \\
\quad=0.0536\end{array}$ & $\begin{array}{c}33,327 / 5178 / \\
{\left[R_{\text {int }}\right]=} \\
0.0304\end{array}$ \\
\hline $\begin{array}{l}\text { completeness to } \\
\theta(\%)\end{array}$ & 99.9 & 99.0 & 99.5 \\
\hline $\begin{array}{l}\text { absorption } \\
\text { correction }\end{array}$ & semi-empirical & semi-empirical & semi-empirical \\
\hline $\begin{array}{l}\text { max. and min. } \\
\text { transmis. }\end{array}$ & 0.7461 and 0.5426 & $\begin{array}{l}0.7454 \text { and } \\
0.2515\end{array}$ & $\begin{array}{c}0.7461 \text { and } \\
0.5031\end{array}$ \\
\hline $\begin{array}{l}\text { refinement } \\
\text { method }\end{array}$ & $\begin{array}{l}\text { full matrix least- } \\
\text { squares on }|F|^{2}\end{array}$ & $\begin{array}{l}\text { full matrix least- } \\
\text { squares on }|F|^{2}\end{array}$ & $\begin{array}{l}\text { full matrix least- } \\
\text { squares on }|F|^{2}\end{array}$ \\
\hline $\begin{array}{c}\text { data/restrains/ } \\
\text { parameters }\end{array}$ & $7586 / 0 / 289$ & $3019 / 0 / 154$ & $5178 / 0 / 154$ \\
\hline $\begin{array}{l}\text { goodness of fit } \\
\left(\text { GOF) on }|F|^{2}\right.\end{array}$ & 1.066 & 1.063 & 1.254 \\
\hline $\begin{array}{l}\text { final } R \text { indices }[I \\
\quad>2 \sigma(I)]\end{array}$ & $\begin{array}{l}R_{1}=0.0224, w R_{2} \\
\quad=0.0437\end{array}$ & $\begin{array}{l}R_{1}=0.0228, w R_{2} \\
\quad=0.0545\end{array}$ & $\begin{array}{l}R_{1}=0.0279 \\
w R_{2}=0.0584\end{array}$ \\
\hline $\begin{array}{l}R \text { indices (all } \\
\text { data) }\end{array}$ & $\begin{array}{l}R_{1}=0.0340, w R_{2} \\
\quad=0.0503\end{array}$ & $\begin{array}{l}R_{1}=0.0238, w R_{2} \\
\quad=0.0550\end{array}$ & $\begin{array}{l}R_{1}=0.0390 \\
w R_{2}=0.0659\end{array}$ \\
\hline $\begin{array}{l}\text { extinction } \\
\text { coefficient }\end{array}$ & $\mathrm{n} / \mathrm{a}$ & $\mathrm{n} / \mathrm{a}$ & $\mathrm{n} / \mathrm{a}$ \\
\hline $\begin{array}{l}\text { largest diff. peak } \\
\text { and hole (e } \\
\left.\AA^{-3}\right)\end{array}$ & 1.542 and -1.644 & 1.408 and -2.586 & $\begin{array}{c}1.663 \text { and } \\
-1.871\end{array}$ \\
\hline
\end{tabular}


Table 11. Crystal Structure Refinement Data for Compounds 4-6

\begin{tabular}{|c|c|c|c|}
\hline parameters & 4 & 5 & 6 \\
\hline empirical formula & $\mathrm{C}_{24} \mathrm{H}_{20} \mathrm{Cl}_{4} \mathrm{HgN}_{4} \mathrm{O}$ & $\mathrm{C}_{24} \mathrm{H}_{18} \mathrm{Br}_{4} \mathrm{HgN}_{4}$ & $\mathrm{C}_{24} \mathrm{H}_{18} \mathrm{I}_{4} \mathrm{HgN} 4$ \\
\hline formula weigh & 722.83 & 882.65 & 1070.61 \\
\hline$T(\mathrm{~K})$ & $100(2)$ & $100(2)$ & $100(2)$ \\
\hline wavelength $(\AA)$ & 0.71073 & 0.71073 & 0.71073 \\
\hline system, space group & monoclinic, $P 2_{1} / c$ & triclinic, $P-1$ & monoclinic, $P 2 / m$ \\
\hline \multicolumn{4}{|l|}{ unit cell dimensions } \\
\hline$a(\AA)$ & $16.3186(6)$ & $7.8160(7)$ & $8.991(3)$ \\
\hline$b(\AA)$ & $10.6960(4)$ & $9.0601(8)$ & $19.040(8)$ \\
\hline$c(\AA)$ & $14.6085(5)$ & $18.7870(17)$ & $9.004(3)$ \\
\hline$\alpha\left(^{\circ}\right)$ & 90 & $86.438(3)$ & 90 \\
\hline$\beta\left({ }^{\circ}\right)$ & $107.8560(10)$ & $86.462(3)$ & $93.322(13)$ \\
\hline$\gamma\left({ }^{\circ}\right)$ & 90 & $66.489(3)$ & 90 \\
\hline$V\left(\AA^{3}\right)$ & $2427.00(15)$ & $1216.59(19)$ & $1538.8(10)$ \\
\hline$Z$ & 4 & 2 & 2 \\
\hline$D_{\text {calc }}\left(\mathrm{g} \mathrm{cm}^{3}\right)$ & 1.978 & 2.409 & 2.311 \\
\hline$\mu\left(\mathrm{mm}^{-1}\right)$ & 6.809 & 12.916 & 9.031 \\
\hline$F(000)$ & 1392 & 820 & 964 \\
\hline Crystal size $\left(\mathrm{mm}^{3}\right)$ & $0.447 \times 0.417 \times 0.360$ & $0.372 \times 0.149 \times 0.137$ & $0.360 \times 0.179 \times 0.057$ \\
\hline \multirow[t]{3}{*}{$h k l$ ranges } & $-23 \leq h \leq 22$ & $-11 \leq h \leq 11$ & $-12 \leq h \leq 12$ \\
\hline & $0 \leq k \leq 15$ & $-12 \leq k \leq 12$ & $-26 \leq k \leq 27$ \\
\hline & $0 \leq l \leq 20$ & $0 \leq l \leq 26$ & $-11 \leq l \leq 12$ \\
\hline $2 \theta$ range $\left(^{\circ}\right)$ & $2.312-30.522$ & $2.454-30.589$ & $2.506-30.516$ \\
\hline reflections collected/unique/[ $\left.R_{\mathrm{int}}\right]$ & $7241 / 7241 /\left[R_{\mathrm{int}}\right]=0.0522$ & $7217 / 7217 /\left[R_{\mathrm{int}}\right]=0.0462$ & $35,555 / 4787 /\left[R_{\mathrm{int}}\right]=0.0293$ \\
\hline completeness to $\theta(\%)$ & 98.2 & 97.2 & 98.9 \\
\hline absorption correction & semi-empirical & semi-empirical & semi-empirical \\
\hline max. and min. transmis. & 0.7461 and 0.2506 & 0.7461 and 0.3802 & 0.7461 and 0.4860 \\
\hline refinement method & full matrix least-squares on $|F|^{2}$ & full matrix least-squares on $|F|^{2}$ & full matrix least-squares on $|F|^{2}$ \\
\hline data/restrains/parameters & $7241 / 3 / 313$ & $7217 / 0 / 298$ & $4787 / 25 / 90$ \\
\hline goodness of fit (GOF) on $|F|^{2}$ & 1.059 & 1.104 & 1.132 \\
\hline final $R$ indices $[I>2 \sigma(I)]$ & $R_{1}=0.0223, w R_{2}=0.0540$ & $R_{1}=0.0389, w R_{2}=0.0986$ & $R_{1}=0.0419, w R_{2}=0.0983$ \\
\hline$R$ indices (all data) & $R_{1}=0.0241, w R_{2}=0.0547$ & $R_{1}=0.0398, w R_{2}=0.0992$ & $R_{1}=0.0487, w R_{2}=0.1032$ \\
\hline extinction coefficient & $\mathrm{n} / \mathrm{a}$ & $\mathrm{n} / \mathrm{a}$ & $\mathrm{n} / \mathrm{a}$ \\
\hline largest diff. peak and hole (e $\left.\AA^{-3}\right)$ & 1.602 and -2.548 & 1.600 and -2.138 & 2.617 and -1.774 \\
\hline
\end{tabular}

for some transition metal oxides, the D2 correction leads to cell parameters that are closer to experimental data than D3. ${ }^{52,53}$ Ionic cores were described with projector-augmented wave pseudopotentials, ${ }^{54,55}$ and the valence electrons were represented through a plane wave basis set with a kinetic energy cutoff of $400 \mathrm{eV}$. A $(4,4,4)$ Monkhorst-Pack K-point mesh $^{56}$ was employed to describe the Brillouin zone. The energy convergence criteria were fixed to $10^{-5}$ and $10^{-4} \mathrm{eV}$ for electronic and geometry relaxations, respectively. Further details about crystal structure refinement and electronic calculations are in the Supporting Information.

\section{ASSOCIATED CONTENT}

\section{SI Supporting Information}

The Supporting Information is available free of charge at https://pubs.acs.org/doi/10.1021/acsomega.0c04175.

Crystallographic data of compound $\mathbf{1}$ (CIF)

Crystallographic data of compound 2 (CIF)

Crystallographic data of compound 3 (CIF)

Crystallographic data of compound 4 (CIF)

Crystallographic data of compound $\mathbf{5}$ (CIF)

Crystallographic data of compound 6 (CIF)

Further details about crystal structures refinement, electronic calculations, PXRD, FTIR-ATR and ${ }^{1} \mathrm{H}$ NMR spectra, and TG/DTA determination (PDF)

\section{Accession Codes}

CCDC 2012988-2012993 contain the supplementary crystallographic data for this paper. These data can be obtained free of charge via www.ccdc.cam.ac.uk/data_request/cif, by emailing data_request@ccdc.cam.ac.uk, or by contacting The Cambridge Crystallographic Data Centre, 12 Union Road, Cambridge CB2 1EZ, UK; fax: +44 1223336033.

\section{AUTHOR INFORMATION}

\section{Corresponding Author}

Josefina Pons - Departament de Quimica, Universitat Autonoma de Barcelona, Barcelona 08193, Spain; ○ orcid.org/0000-0002-9546-6828; Email: Josefina.Pons@ uab.es

\section{Authors}

Francisco Sánchez-Férez - Departament de Química, Universitat Autònoma de Barcelona, Barcelona 08193, Spain

Xavier Solans-Monfort - Departament de Quimica, Universitat Autònoma de Barcelona, Barcelona 08193, Spain

Teresa Calvet - Departament de Mineralogia, Petrologia $i$ Geologia Aplicada, Universitat de Barcelona, Barcelona 08028, Spain

Mercè Font-Bardia - Unitat de Difracció de Raig-X, Centres Científics $i$ Tecnologics de la Universitat de Barcelona (CCiTUB), Universitat de Barcelona, Barcelona 08028, Spain 
Complete contact information is available at:

https://pubs.acs.org/10.1021/acsomega.0c04175

\section{Notes}

The authors declare no competing financial interest.

\section{ACKNOWLEDGMENTS}

J.P. acknowledges financial support from the CB615921 project, the CB616406 project from "Fundació La Caixa", and the 2017SGR1687 project from the Generalitat de Catalunya. X.S.M. acknowledges financial support from MINECO (CTQ2017-89132-P) and the Generalitat de Catalunya (2017SGR132). F.S.F. acknowledges the PIF predoctoral fellowship from the Universitat Autonoma de Barcelona. X.S.M. is also grateful for the Professor Agregat Serra Húnter position.

\section{REFERENCES}

(1) Zarick, H. F.; Soetan, N.; Erwin, W. R.; Bardhan, R. Mixed Halide Hybrid Perovskites: A Paradigm Shift in Photovoltaics. J. Mater. Chem. A 2018, 6, 5507-5537.

(2) Oswald, I. W. H.; Ahn, H.; Neilson, J. R. Influence of Organic Cation Planarity on Structural Templating in Hybrid Metal-Halides. Dalton Trans. 2019, 48, 16340-16349.

(3) Chatterjee, S.; Pal, A. J. Influence of Metal Substitution on Hybrid Halide Perovskites: Towards Lead-Free Perovskite Solar Cells. J. Mater. Chem. A 2018, 6, 3793-3823.

(4) Berryman, O. B.; Bryantsev, V. S.; Stay, D. P.; Johnson, D. W.; Hay, B. P. Structural Criteria for the Design of Anion Receptors: The Interaction of Halides with Electron-Deficient Arenes. J. Am. Chem. Soc. 2007, 129, 48-58.

(5) Albrecht, M.; Wessel, C.; De Groot, M.; Rissanen, K.; Lüchow, A. Structural Versatility of Anion- $\pi$ Interactions in Halide Salts with Pentafluorophenyl Substituted Cations. J. Am. Chem. Soc. 2008, 130, 4600-4601.

(6) Lim, J. Y. C.; Beer, P. D. Sigma-Hole Interactions in Anion Recognition. Chem 2018, 4, 731-783.

(7) Politzer, P.; Murray, J. S.; Clark, T.; Resnati, G. The $\sigma$-Hole Revisited. Phys. Chem. Chem. Phys. 2017, 19, 32166-32178.

(8) Nepal, B.; Scheiner, S. NX ‥Y Halogen Bonds. Comparison with NH...Y H-Bonds and CX...Y Halogen Bonds. Phys. Chem Chem. Phys. 2016, 18, 18015-18023.

(9) Melandri, S. "Union Is Strength": How Weak Hydrogen Bonds Become Stronger. Phys. Chem. Chem. Phys. 2011, 13, 13901-13911.

(10) Oswald, I. W. H.; Mozur, E. M.; Moseley, I. P.; Ahn, H.; Neilson, J. R. Hybrid Charge-Transfer Semiconductors: $\left(\mathrm{C}_{7} \mathrm{H}_{7}\right) \mathrm{SbI}_{4}$, $\left(\mathrm{C}_{7} \mathrm{H}_{7}\right) \mathrm{BiI}_{4}$, and Their Halide Congeners. Inorg. Chem. 2019, 58, 5818-5826.

(11) Savory, C. N.; Palgrave, R. G.; Bronstein, H.; Scanlon, D. O. Spatial Electron-Hole Separation in a One Dimensional Hybrid Organic-Inorganic Lead Iodide. Sci. Rep. 2016, 6, 20626-20627.

(12) Chen, W. T.; Zeng, X. R.; Fang, X. N.; Li, X. F.; Liu, L. M. Synthesis, Structure and Properties of $\left(4,4^{\prime}-\mathrm{H}_{2} \mathrm{Bipy}\right)\left[\mathrm{HgBr}_{4}\right] \cdot \mathrm{H}_{2} \mathrm{O}$ with Strong Fluorescence. Inorg. Chem. Commun. 2007, 10, 223-225.

(13) Smith, I. C.; Hoke, E. T.; Solis-Ibarra, D.; McGehee, M. D.; Karunadasa, H. I. A Layered Hybrid Perovskite Solar-Cell Absorber with Enhanced Moisture Stability. Angew. Chem. 2014, 53, 1123211235 .

(14) Mao, L.; Stoumpos, C. C.; Kanatzidis, M. G. Two-Dimensional Hybrid Halide Perovskites: Principles and Promises. J. Am. Chem. Soc. 2019, 141, 1171-1190.

(15) Cheng, P.; Wang, P.; Xu, Z.; Jia, X.; Wei, Q.; Yuan, N.; Ding, J.; Li, R.; Zhao, G.; Cheng, Y.; Zhao, K.; Liu, S. F. Ligand-Size Related Dimensionality Control in Metal Halide Perovskites. ACS Energy Lett. 2019, 4, 1830-1838.
(16) Albero, J.; Asiri, A. M.; García, H. Influence of the Composition of Hybrid Perovskites on Their Performance in Solar Cells. J. Mater. Chem. A 2016, 4, 4353-4364.

(17) Saparov, B.; Mitzi, D. B. Organic-Inorganic Perovskites: Structural Versatility for Functional Materials Design. Chem. Rev. 2016, 116, 4558-4596.

(18) Bharara, M. S.; Bui, T. H.; Parkin, S.; Atwood, D. A. StructureDirecting Influence of Halide in Mercury Thiolate Clusters. Inorg. Chem. 2005, 44, 5753-5760.

(19) Bharara, M. S.; Bui, T. H.; Parkin, S.; Atwood, D. A. Mercurophilic Interaction in Novel Polynuclear Hg(II)-2- Aminoethanethiolates. Dalton Trans. 2005, 3874-3880.

(20) Bharara, M. S.; Parkin, S.; Atwood, D. A. Solution and SolidState Study of Heteroleptic $\mathrm{Hg}$ (II)-Thiolates: Crystal Structures of $\left[\mathrm{Hg}_{4} \mathrm{I}_{4}\left(\mathrm{SCH}_{2} \mathrm{CH}_{2} \mathrm{NH}_{2}\right)_{4}\right]$ and $\left[\mathrm{Hg}_{4} \mathrm{I}_{8}\left(\mathrm{SCH}_{2} \mathrm{CH}_{2} \mathrm{NH}_{3}\right)_{2}\right]$. Inorg. Chem. 2006, 45, 2112-2118.

(21) Bharara, M. S.; Parkin, S.; Atwood, D. A. Mercury(II) 2Aminoethanethiolate Clusters: Intramolecular Transformations and Mechanisms. Inorg. Chem. 2006, 45, 7261-7268.

(22) Spengler, R.; Zouari, R.; Zimmermann, H.; Ben Salah, A.; Burzlaff, H. 1,3-Propanediammonium Tetrachloromercurate. Acta Crystallogr. Sect. C Cryst. Struct. Commun. 1998, 54, 1628-1631.

(23) Amami, M.; Zouari, R.; Ben Salah, A.; Burzlaff, H. 1,4Butanediammonium Tetrachloromercurate(II). Acta Crystallogr., Sect. E 2002, 58, m357-m359.

(24) Belhouchet, M.; Wamani, W.; Mhiri, T. Synthesis, Structure and Spectroscopic Investigations of Two New Organic-Inorganic Hybrids $\mathrm{NH}_{3}\left(\mathrm{C}_{6} \mathrm{H}_{4}\right)_{2} \mathrm{NH}_{3} \mathrm{CuCl}_{4}$ and $\mathrm{NH}_{3}\left(\mathrm{C}_{6} \mathrm{H}_{4}\right)_{2} \mathrm{NH}_{3} \mathrm{HgCl}$. IOP Conf. Ser.: Mater. Sci. Eng. 2010, 13, No. 012039.

(25) Barbieri, A.; Accorsi, G.; Armaroli, N. Luminescent Complexes beyond the Platinum Group: The $\mathrm{d}^{10}$ Avenue. Chem. Commun. 2008, 2185-2193.

(26) Guerrero, M.; Vázquez, S.; Ayllón, J. A.; Calvet, T.; FontBardia, M.; Pons, J. Zn(II) and Cd(II) Coordination Dimers Based on Mixed Benzodioxole-Carboxylate and N-Donor Ligands: Synthesis, Characterization, Crystal Structures and Photoluminescence Properties. ChemistrySelect 2017, 2, 632-639.

(27) Ejarque, D.; Sánchez-Férez, F.; Ayllón, J. A.; Calvet, T.; FontBardia, M.; Pons, J. Diverse Structures and Dimensionalities in $\mathrm{Zn}(\mathrm{II}), \mathrm{Cd}(\mathrm{II})$, and $\mathrm{Hg}(\mathrm{II})$ Metal Complexes with Piperonylic Acid. Cryst. Growth Des. 2020, 20, 383-400.

(28) Moreno-Gómez, L.; Sánchez-Férez, F.; Calvet, T.; Font-Bardia, M.; Pons, J. Zn(II) and Cd(II) Monomer, Dimer and Polymer Compounds Coordinated by Benzoic Acid and 4-Acetylpyridine: Synthesis and Crystal Structures. Inorg. Chim. Acta 2020, 506, 119561.

(29) Ali, B. F.; Al-Far, R. Isostructural Series of (2,2'-Bipyridinium) Tetrabromometallate(II); Intermolecular Interactions in the Structures of $\left(\mathrm{BpyH}_{2}\right)\left[\mathrm{MBr}_{4}\right] ; \mathrm{M}=\mathrm{Zn} \mathrm{Hg}$ and Co. J. Chem. Crystallogr. 2008, 38, 689-693.

(30) Tsuge, M.; Lai, C. P.; Lee, Y. P. Infrared Spectra of 3-Hydroxy(1H)-Pyridinium Cation and 3-Hydroxy-(1H)-Pyridinyl Radical Isolated in Solid Para -Hydrogen. J. Chem. Phys. 2018, 149, No. 014306.

(31) Rutkowski, K. S.; Melikova, S. M.; Rospenk, M.; Koll, A. Strong and Weak Effects Caused by Non Covalent Interactions between Chloroform and Selected Electron Donor Molecules. Phys. Chem. Chem. Phys. 2011, 13, 14223-14234.

(32) Golec, B.; Das, P.; Bahou, M.; Lee, Y.-P. Infrared Spectra of the 1-Pyridinium $\left(\mathrm{C}_{5} \mathrm{H}_{5} \mathrm{NH}^{+}\right)$Cation and Pyridinyl $\left(\mathrm{C}_{5} \mathrm{H}_{5} \mathrm{NH}\right.$ and 4$\left.\mathrm{C}_{5} \mathrm{H}_{6} \mathrm{~N}\right)$ Radicals Isolated in Solid Para-Hydrogen. J. Phys. Chem. A 2013, 117, 13680-13690.

(33) Williams, D. H.; Fleming, I. Spectroscopic Methods in Organic Chemistry; 7th ed.; Springer Nature: Cham, Switzerland, 2008.

(34) Teleb, S. M.; Gaballa, A. S. Preparation and Spectroscopic Studies on Charge-Transfer Complexes of 2,2'-Bipyridine with Picric and Chloranilic Acids. Spectrochim. Acta, Part A 2005, 62, 140-145.

(35) Yang, L.; Powell, D. R.; Houser, R. P. Structural Variation in Copper(I) Complexes with Pyridylmethylamide Ligands: Structural 
Analysis with a New Four-Coordinate Geometry Index, T4. J. Chem. Soc Dalton Trans. 2007, 9, 955-964.

(36) Rabeand, S.; Müller, U. Crystal Structure of Bis(Tetraphenylphosphonium) Octachlorotrimercurate, [P$\left.\left(\mathrm{C}_{6} \mathrm{H}_{5}\right)_{4}\right]_{2}\left[\mathrm{Hg}_{3} \mathrm{Cl}_{8}\right]$. Zeitschrift für Krist. - New Cryst. Struct. 1999, 214, 277-278.

(37) Fernando, I. R.; Mezei, G. Blue-Colored, Linear Rigid-Axle [2]Pseudorotaxanes: Metal-Binding Properties, Crystal Structures, and Blue/Red Dichroism. Inorg. Chem. 2012, 51, 3156-3160.

(38) Xu, L.; Gao, J. X.; Chen, X. G.; Hua, X. N.; Wu, D. H.; Liao, W. Q. Unprecedented Dielectric Bistable Switching in a Binuclear $\mathrm{Hg}(\mathrm{II})$ Based Hybrid Compound. Eur. J. Inorg. Chem. 2019, 2019, 800-807.

(39) Oueslati, A.; Chaabane, I.; Adil, K.; Hlel, F. Structural Characterization and Infrared and Electrical Properties of the New Inorganic-Organic Hybrid Compound $\left[\mathrm{N}\left(\mathrm{C}_{3} \mathrm{H}_{7}\right)_{4}\right]_{2}\left[\mathrm{Hg}_{2} \mathrm{Cl}_{6}\right]$. J. Chem. 2013, 2013, 1-10.

(40) Chen, J.-X.; Zhang, W.-H.; Ren, Z.-G.; Zhang, Y.; Lang, J.-P. Bis[4(Trimethylammonio)Phenyl]Disulfide Tetraiodomercurate(II). Acta Crystallogr., Sect. E: Struct. Rep. Online 2005, 61, 60-62.

(41) Ishihara, H.; Horiuchi, K.; Svoboda, I.; Fuess, H.; Gesing, T. M.; Buhl, J.-C.; Terao, H. Crystal Structures of Piperazinium Tetrahalogenometallates (II) $\left[\mathrm{C}_{4} \mathrm{H}_{12} \mathrm{~N}_{2}\right] \mathrm{MX}_{4}(\mathrm{M}=\mathrm{Zn}, \mathrm{Hg} ; \mathrm{X}=\mathrm{Br}$, I). Z. Naturforsch. B 2006, 61, 69-72.

(42) Ye, Z. Y.; Zhang, Z. Y.; Huo, L. H.; Deng, Z. P.; Zhang, X. F.; Gao, S. Mercury Supramolecular Architectures Constructed from Flexible Unsymmetrical Bis(Pyridyl) Ligands: Structural Motif Mediated by Mercury-Halide Clusters, Ligand Conformations and Non-Covalent Interactions. Polyhedron 2016, 117, 338-351.

(43) Govindan, E.; Thirumurugan, S.; Ganeshraja, A. S.; Anbalagan, K.; Subbiahpandi, A. Bis(1,10-Phenanthrolin-1-Ium) Tetrachloridozincate Monohydrate. Acta Crystallogr., Sect. E 2014, 70, m53.

(44) Feng, G.; Evangelisti, L.; Favero, L. B.; Grabow, J. U.; Xia, Z.; Caminati, W. On the Weak O-H...halogen Hydrogen Bond: A Rotational Study of $\mathrm{CH}_{3} \mathrm{CHClF} \cdots \mathrm{H}_{2} \mathrm{O}$. Phys. Chem. Chem. Phys. 2011, 13, 14092-14096.

(45) Turner, M. J.; McKinnon, J. J.; Wolff, S. K.; Grimwood, D. J.; Spackman, P. R.; Jayatilaka, D.; Spackman, M. A. CrystalExplorer17. University of Western Australia, 2017.

(46) Hernández-Haro, N.; Ortega-Castro, J.; Martynov, Y. B.; Nazmitdinov, R. G.; Frontera, A. DFT Prediction of Band Gap in Organic-Inorganic Metal Halide Perovskites: An Exchange-Correlation Functional Benchmark Study. Chem. Phys. 2019, 516, 225-231.

(47) Göller, A.; Grummt, U. W. Torsional Barriers in Biphenyl, 2,2' Bipyridine and 2-Phenylpyridine. Chem. Phys. Lett. 2000, 321, 399405.

(48) Perdew, J. P.; Burke, K.; Ernzerhof, M. Generalized Gradient Approximation Made Simple. Phys. Rev. Lett. 1996, 77, 3865-3868.

(49) Grimme, S. Accurate Description of Van Der Waals Complexes by Density Functional Theory Including Empirical Corrections. J. Comput. Chem. 2004, 25, 1463-1473.

(50) Kresse, G.; Hafner, J. Ab Initio Molecular Dynamics for Liquid Metals. Phys. Rev. B 1993, 47, 558-561.

(51) Kresse, G.; Furthmüller, J. Efficient Iterative Schemes for Ab Initio Total-Energy Calculations Using a Plane-Wave Basis Set. Phys. Rev. B 1996, 54, 11169-11186.

(52) Heras-Domingo, J.; Sodupe, M.; Solans-Monfort, X. Interaction between Ruthenium Oxide Surfaces and Water Molecules. Effect of Surface Morphology and Water Coverage. J. Phys Chem. C 2019, 123, 7786-7798.

(53) González, D.; Heras-Domingo, J.; Pantaleone, S.; Rimola, A.; Rodríguez-Santiago, L.; Solans-Monfort, X.; Sodupe, M. Water Adsorption on $\mathrm{MO}_{2}(\mathrm{M}=\mathrm{Ti}, \mathrm{Ru}$, and Ir) Surfaces. Importance of Octahedral Distortion and Cooperative Effects. ACS Omega 2019, 4, 2989-2999.

(54) Blöchl, P. E. Projector Augmented-Wave Method. Phys. Rev. B 1994, 50, 17953-17979.

(55) Kresse, G.; Joubert, D. From Ultrasoft Pseudopotentials to the Projector Augmented-Wave Method. Phys. Rev. B - Condens. Matter Mater. Phys. 1999, 59, 1758-1775.
(56) Pack, J. D.; Monkhorst, H. J. "special Points for Brillouin-Zone Integrations”-a Reply. Phys. Rev. B 1977, 16, 1748-1749. 